\title{
COMMERCIAL SPEECH IN THE PROFESSIONS: THE SUPREME COURT'S UNANSWERED QUESTIONS AND QUESTIONABLE ANSWERS
}

\author{
FRED S. MCCHESNEY ${ }^{\dagger}$
}

\section{INTRODUCTION}

In Virginia State Board of Pharmacy v. Virginia Citizens Consumer Council, ${ }^{1}$ the Supreme Court rendered the first of several rulings extending partial first amendment protection to commercial speech. Most of the cases that have defined and refined the "commercial speech doctrine" have involved state restrictions on the ability of members of licensed professions, such as lawyers, pharmacists and optometrists, to promote themselves. Restrictions on advertising, solicitation and tradename use have all been challenged.

Although the constitutional test applied in each case has ostensibly been the same, the degree of protection accorded by the Court under the commercial speech doctrine has varied, depending on the type of promotion at issue. The Court has granted considerably greater protection to advertising than to other forms of promotion. Virginia Pharmacy, which introduced commercial speech-protection, held that a state ban on price advertising by pharmacists was constitutionally infirm. In Bates v. State Bar of Arizona, ${ }^{2}$ the Court extended that holding, striking down a ban on advertising by attorneys. The Court further expanded the protection of commercial speech in In re R.M.J., ${ }^{3}$ in which it held that unreasonable restrictions on lawyer advertising, though short of an outright ban, nevertheless run afoul of the first amendment. Most recently, in Zauderer $v$. Office of Disciplinary Counsel, ${ }^{4}$ the Court struck down a state's prohibition on attorney advertising that contained information directed at a particular clientele regarding specific legal problems. Freed by the Supreme Court from traditional state

† Associate Professor of Law, Emory University. A.B. 1970, Holy Cross College; J.D. 1978, University of Miami; Ph.D. (economics) 1982, University of Virginia. Research assistance from Thomas Gannon and Kim Garman is gratefully acknowledged. Helpful comments were received from Henry Butler, Richard Craswell and John Preston, and from members of the Emory faculty, particularly David Haddock and Thomas Morgan.

1425 U.S. 748,770 (1976).

2433 U.S. 350,384 (1977).

3455 U.S. 191, 207 (1982).

105 S. Ct. 2265, 2279-80 (1985). 
restrictions, "advertising by professionals . . . has increased steadily over the past several years and looks to a healthy future."s

Restrictions on nonadvertising promotion have fared differently. The Court in Ohralik v. Ohio State Bar ${ }^{6}$ ruled that the first amendment does not prevent a state from banning in-person, commercial solicitation by lawyers. ${ }^{7}$ In Friedman $v$. Rogers, ${ }^{8}$ the Court upheld, against first amendment challenge, a state's ability to ban the use of trade names by optometrists. In both cases, the Court concluded that the possibility of consumers being deceived sufficed to deny constitutional protection to the commercial speech in question.

Gommentators' reactions to the Court's commercial speech cases have been unusual. Almost all applaud promotion in the professions; few accept the Court's particular delimitation of professionals' promotional rights. Noting that the Court's reasoning in the cases has rested more on economic analysis than on traditional first amendment principles, some scholars who favor professional promotion as an economic proposition nevertheless would not protect it constitutionally. ${ }^{9}$ Another S-1.

- Alter, No Pot of Gold, Just Satisfaction, Advertising Age, Dec. 24, 1979, at

B 436 U.S. 447 (1978).

${ }^{7}$ Id. at 468. But see In re Primus, 436 U.S. 412, 434-39 (1978) (Solicitation on behalf of nonprofit, "public-interest" organization is not commercial speech and is accorded full first-amendment protection.).

s 440 U.S. 1, 15-16 (1979).

See, e.g., Attanasio, Lawyer Advertising in England and the United States, 32 AM. J. CoMP. L. 493, 516 (1984) ("[F]orbidding regulation of advertising moves toward revisiting $\mathrm{Mr}$. Justice Holmes' warning of constitutionalizing a particular economic system which, in turn, narrows political choice."); Baker, Commercial Speech: A Problem in the Theory of Freedom, 62 Iowa L. REv. 1, 3 (1976) ("Commercial speech lacks the crucial connections with individual liberty and self-realization which exist for speech generally, and which are central to justifications for the constitutional protection of speech . . . "); Jackson \& Jeffries, Commercial Speech: Economic Due Process and the First Amendment, 65 VA. L. REv. 1, 30 (1979) (Statutes banning drug price advertising may be economically unwise, but should not be held unconstitutional.); see also Canby, Commercial Speech of Lawyers: The Court's Unsteady Course, 46 BRookLYN L. REV. 401, 404 (1980) ("The establishment of a standard of review for commercial speech lower than that applied to political speech is not without its doctrinal and practical difficulties."); Canby \& Gellhorn, Physician Advertising: The First Amendment and the Sherman Act, 1978 Duke L.J. 543, 583 ("[T]o achieve a finely tuned policy governing professional regulation that is responsive to economic nuances, the first amendment is hardly the ideal instrument."). See generally T. EMERSON, TOWARD A General Theory OF THE First Amendment 105 n.46 (1966) (Commercial speech "generally relate[s] to a separate sector of social activity involving the system of property rights rather than free expression."); Emerson, First Amendment Doctrine and the Burger Court, 68 CAL. L. REV. 422, 458-61 (1980) (discussing several reasons why the first amendment should not extend to commercial speech). For a criticism of attempts to consider commercial, political and other speech within a single theory of the first amendment, see Shiffrin, The First Amendment and Economic Regulation: Away from a General Theory of the First Amendment, 78 Nw. U.L. REv. 1212 (1983). 
commentator argues just the opposite: because permitting commercial speech is desirable as a matter of economics, it deserves the full first amendment protection accorded political speech. ${ }^{10}$ Others agree that constitutional protection of commercial speech is warranted but find that the Court's opinions fail to achieve continuity of analysis or consistency of result. ${ }^{11}$

The Court's refusal to extend even limited first amendment protection to nonadvertising forms of promotion. such as solicitation concerns still others, who feel that a total ban on solicitation is overly broad. ${ }^{12}$ This objection is perhaps the most topical one today. The American Bar Association's Commission on Evaluation of Professional Standards and the ABA's new Model Rules of Professional Conduct continue the Court's distinction between advertising and solicitation by permitting only the former. ${ }^{13}$ The Model Rules deem the latter "fraught with the possibility of undue influence, intimidation, and over-reaching."14 The Rules' advertising/solicitation distinction has elicited a sharp rebuke from the Assistant Attorney General for Antitrust, who charged that the continued ban on solicitation is "anticompetitive" and "generally inhibits those in most need of information

10 See Coase, Advertising and Free Speech, 6 J. Legal STUd. 1 (1977); Coase, The Market for Goods and the Market for Ideas, AM. Econ. REv., May 1974, at 384 (Papers and Proceedings).

11 See, e.g., Canby, supra note 9, at 401 ("We have learned to expect some theoretical inconsistency in the Court's decisions when it first opens up new constitutional territory, and in the field of professional advertising and solicitation we have not been disappointed."); Liebeler, The Essence of Chaos: The Supreme Court, Advertising and the First Amendment, Wash. St. B. News, Feb. 1980, at 14, 22 (objecting to the "wholly arbitrary manner" in which commercial speech cases have been decided); see also Andrews, Lawyer Advertising and the First Amendment, 1981 AM. B. Found. RESEARCH J. 967, 982 (noting criticisms of the "fluctuating rationales" of commercial speech cases).

12 Joe Sims, a member of the Washington, D.C. Bar's Committee on Legal Ethics and the Special Committee of the D.C. Bar on the Model Rules of Professional Conduct, criticizes the ABA's maintenance of the advertising/solicitation distinction, arguing that the two are conceptually indistinguishable. See Sims, ABA Still Balks at Reasonable Advertising Reform, Legal Times, March 28, 1983, at 11, col. 2; see also Christensen, Advertising by Lawyers, 1978 UTAH L. REv. 619, 632 ("Pressure continues to mount for a rule that would permit any form of advertising, including solicitation, that is not false, deceptive or misleading."). For citation to others critical of prohibitions on solicitation, see Note, Soliciting Sophisticates: A Modest Proposal for Attorney Solicitation, 16 U. Mich. J.L. REF. 585, 585 n.4, 589 n.25 (1983).

13 See Model Rules of Professional Conduct Rule 7.2 (1983) (generally permitting advertising that is not false or misleading); $i d$. Rule 7.3 (generally outlawing solicitation); MODel. Rules of Professional. Conduct Rule DR 2-101 (Alternative Draft 1981) (generally permitting advertising that does not involve personal contact and that is not false or misleading); id. Rule DR 2-104 (generally restricting solicitation).

14 Model Rules of Professional Conduct Rule 7.3 comment (1983). 
about the availability of legal services from receiving them."15 Thus, as the state bars take up the question whether to adopt the new Model Rules, the viability of the distinction between advertising and other forms of promotion is far from well accepted.

This article does not dispute the Supreme Court's decision that the first amendment protects commercial speech, but rather joins the criticism of the developing commercial speech doctrine as it applies to promotion by professionals. The article argues that there is no principled reason to treat nonadvertising forms of promotion differently from advertising. In reaching this conclusion, the article questions many of the conclusions that the Court has reached in the issues it has addressed and raises a number of issues previously ignored. Section I briefly reviews the relevant cases, and notes that, although the Supreme Court has used a cost-benefit model to analyze commercial speech in the professions, the Court has been unable or unwilling to apply the model consistently or coherently. Section II attempts to remedy that deficiency by demonstrating that the Court has been remiss in ignoring a major cost of restrictions on speech, the competitive effects of promotional bans in the professions. The issue of consumer deception arising from nonadvertising forms of professional promotion, which the Court has found to require special treatment, is analyzed in Section III.

\section{Commercial Speech and the Professions: The Doctrine}

In deciding whether to grant constitutional protection to particular types of professional promotion, the Supreme Court has not relied on traditional first amendment analysis. Rather, the Court in evolving its commercial speech doctrine has looked to many of the same interests protected by antitrust and consumer protection law. ${ }^{16}$ The debate in the

15 Letter from J. Paul McGrath, Assistant Attorney General, Antitrust Division, Department of Justice, to Honorable Clement C. Torbet, Jr., Chief Justice, Supreme Court of Alabama 5 (Sept. 21, 1984) [on file with the University of Pennsylvania Law Review] [hereinafter cited as McGrath Letter]; see also Letter from Jonathan C. Rose, Assistant Attorney General, Office of Legal Policy, Department of Justice, to Robert J. Kutak 6-7 (July 23, 1982) (calling proposed Model Rule 7.3 "too restrictive") [on file with the University of Pennsylvania Law Review] [hereinafter cited as Rose Letter]. The Justice Department has also criticized the new Model Rules pertaining to advertising and specialization. See McGrath Letter, supra, at 6-7; Rose Letter, supra, at 89.

16 Writing after Bates, Canby and Gellhorn noted the Supreme Court's mixture of antitrust and constitutional principles: "[The Court] reached [its] result only after a careful rule of reason analysis, albeit under the first amendment . . . Canby \& Gellhorn, supra note 9, at 579. Attanasio compared antitrust objections to bans on solicitor advertising in England with first amendment challenges to lawyer advertising in America and concluded that "the actual rationales underlying these doctrinal labels are strikingly similar." Attanasio, supra note 9, at 513. 
advertising cases, for example, has concerned the effects of advertising restrictions on prices, entry barriers and quality of services. The Court's refusal to extend commercial speech protection to solicitation and trade names has rested on the possibility of consumer deception, a consideration normally ignored in analyzing political speech under the first amendment. ${ }^{17}$ In essence, as the Court has admitted, the extent of the constitutional protection afforded commercial speech depends on the economic costs and benefits of allowing a particular form of promotion. ${ }^{18}$

A review of the cases, however, discloses that the Court has analyzed the costs and benefits of promotion by professionals somewhat inconsistently. In particular, a comparison between the advertising and the nonadvertising cases reveals numerous problems. The Court treats critical issues, especially deception, quite differently in the two sets of cases. In addition, issues that are apparently crucial in one set of cases are not even raised, much less discussed, in the other set. As the following review of the major cases discloses, the result is a hodgepodge of ad hoc, rather than principled, distinctions among the different promotional techniques used by professionals.

\section{A. Advertising}

\section{Benefits}

In assessing the costs and benefits of advertising, the Supreme Court has not had difficulty concluding that the benefits dominate. Advertising, the Court says quite simply, conveys valuable information. ${ }^{19}$

The similarity between the first amendment and antitrust analyses of professional promotion restrictions plainly appears in the Federal Trade Commission's antitrust action against the American Medical Association and a state and local medical society for restrictions on advertising, solicitation and other commercial practices. See American Medical Ass'n, 94 F.T.C. 701 (1979), modified, 638 F.2d 443 (2d Cir. 1980), affd mem., 455 U.S. 676 (1982). Although the FTC's complaint alleged only antitrust violations, the Commission relied upon the constitutional analysis in Bates v. State Bar of Arizona, 433 U.S. 350 (1977), and Virginia State Bd. of Pharmacy v. Virginia Citizens Consumer Council, 425 U.S. 748 (1976), to analyze the competitive implications of the restrictions. See American Medical Ass'n, 94 F.T.C. at 950-56. See generally Hazard, Pearce \& Stempel, Why Lawyers Should Be Allowed to Advertise: A Market Analysis of Legal Services, 58 N.Y.U. L. REv. 1084, 1087 (1983) (Participants in the debate on lawyer advertising have failed to appreciate that "legal services are a market commodity.").

17 See infra text accompanying notes 92-102.

18 See In re R.M.J., 455 U.S. 191, 200 n.11 (1982) ("The commercial speech doctrine is itself based in part on certain empirical assumptions as to the benefits of advertising.").

19 Virginia State Bd. of Pharmacy v. Virginia Citizens Consumer Council, 425 U.S. 748,754 (1976). 
It is the "traditional mechanism in a free-market economy" for sellers to provide information to potential buyers. ${ }^{20}$ Advertising informs "the public of the availability, nature, and prices of products and services," and so "performs an indispensable role in the allocation of resources in a free enterprise system."21 "In short," the Court concludes, "such speech serves individual and societal interests in assuring informed and reliable decisionmaking." 22

Advertising's value in conveying information means more than just better-informed choices for consumers already using professionals. It means also that some consumers who otherwise would not find or use professionals at all will have the benefits of their services. In Zauderer v. Office of Disciplinary Counsel, ${ }^{23}$ for example, witnesses for the defendant attorney testified that they would not have learned of their legal claims had it not been for the attorney's advertisement. Although opponents of lawyer advertising have argued that protecting such advertising inappropriately "stirs up litigation,"24 the Supreme Court has rejected this argument. The Court admitted in Bates v. State Bar of Arizona $^{25}$ that advertising might lead to more lawsuits but saw this potential increase in the assertion of legal rights as an advantage of advertising. The Court in Zauderer re-emphasized that

we cannot endorse the proposition that a lawsuit, as such, is an evil. Over the course of centuries, our society has settled upon civil litigation as a means for redressing grievances, resolving disputes, and vindicating rights when other means fail. There is no cause for consternation when a person who believes in good faith and on the basis of accurate information regarding his legal rights that he has suffered a legally cognizable injury turns to the courts for a remedy .... ${ }^{\mathbf{2 6}}$

In addition to noting advertising's general role in informing consumers, the Court has recognized the importance of advertising for

20 Bates v. State Bar of Arizona, 433 U.S. 350, 376 (1977); see also id. at 397 (Powell, J., dissenting) ("[A]dvertising is the most commonly used and useful means of providing information as to goods and other services . . . "); Virginia State Bd. of Pharmacy v. Virginia Citizens Consumer Council, 425 U.S. 748, 765 (1976) ("Advertising ... is ... dissemination of information as to who is producing and selling what product, for what reason, and at what price.").

${ }_{21}$ Bates v. State Bar of Arizona, 433 U.S. 350, 364 (1977) (citation omitted).

22 Id. (citation omitted).

23105 S. Ct. 2265, 2273 (1985).

24 See id. at 2277-78; Bates v. State Bar of Arizona, 433 U.S. 350, 375 (1977).

25433 U.S. 350,376 (1977) ("The disciplinary rule [prohibiting lawyers from advertising] likely has served to burden access to legal services . . . .").

${ }^{26}$ Zauderer, $105 \mathrm{~S}$. Ct. at 2278. 
maintaining competition in the professional marketplace. Contrary to professionals' claims that prices must rise when the costs of advertising are added to overhead, ${ }^{27}$ the Court has noted that prices are generally lower when advertising is allowed. ${ }^{28}$ Bans on advertising insulate the seller of professional services from price competition and "open the way for him to make a substantial, and perhaps even excessive, profit . . ." Bates stated that the inability to advertise also erects a barrier to the entry of new firms, and thus will benefit professionals with more established practices. ${ }^{30}$

This contention of the majority in Bates did not go unchallenged, however. In his dissent, Justice Powell suggested that larger, better established firms "often possess the economic power to disadvantage the weaker or more inexperienced firms in any advertising competition."31 The majority believed just the opposite to be true: "In the absence of advertising, an attorney must rely on his contacts with the community to generate a flow of business. In view of the time necessary to develop such contacts, the ban in fact serves to perpetuate the market position of established attorneys." 32

\section{Costs}

In according constitutional protection to advertising, the Court addressed advertising's possible costs but found them outweighed by the benefits of increased information and competition. General objections that the seller's interest was largely economic ${ }^{33}$ and that advertising could be "tasteless and excessive",34 "in poor taste"36 or "embarrassing or offensive"se have been dismissed rather quickly. The Court gave greater consideration to claims that allowing advertising would lower the quality of services that professionals provide and that advertising would foster deception of consumers. Ultimately, however, the Court found both the quality and deception arguments insufficient to outweigh the benefits of advertising.

27 Bates, 433 U.S. at 377.

28 Id.

29 Virginia State Bd. of Pharmacy v. Virginia Citizens Consumer Council, 425 U.S. 748, 769 (1976).

${ }^{30}$ Bates, 433 U.S. at 378.

s1 Id. at 403 n.13 (Powell, J., dissenting).

32 Id. at 378 .

ss See id. at 364; Zauderer, 105 S. Ct. at 2276 ("[A]ll advertising is at least implicitly a plea for its audience's custom . . . .").

34 Virginia State Bd. of Pharmacy v. Virginia Citizens Consumer Council, 425 U.S. 748,765 (1976).

ss Zauderer, 105 S. Ct. at 2277.

${ }^{36} I d$. at 2280. 
Objections that advertising has an adverse effect on quality of services have arisen in various guises, all of which the Court has rejected. Thus, although professional associations have argued that "maintaining a high degree of professionalism" requires a ban on advertising, ${ }^{37}$ the Court has found "the postulated connection between advertising and the erosion of true professionalism to be severely strained."38 According to the Court, "[a]n attorney who is inclined to cut quality will do so regardless of the rule on advertising." 39 The Court's view is consistent with the empirical evidence, which shows that quality of service is at worst unaffected by professionals' ability to advertise, ${ }^{40}$ and may even be associated with a higher quality of professional service. ${ }^{41}$ Moreover, the Court's position reflects the overwhelming view of the members of numerous professions that there is in fact no relationship between ability to promote oneself and quality of service. ${ }^{42}$ Finally, the Court's re-

37 Virginia State Bd. of Pharmacy v. Virginia Citizens Consumer Council, 425 U.S. 748, 766 (1976); see also Bates, 433 U.S. at 368 (challenging the State Bar of Arizona's argument that "price advertising will bring about commercialization, which will undermine the attorney's sense of dignity and self-worth").

${ }^{38}$ Bates, 433 U.S. at 368; accord Virginia State Bd. of Pharmacy v. Virginia Citizens Consumer Council, 425 U.S. 748, 769 (1976) ("The advertising ban does not directly affect professional standards one way or the other.").

${ }^{39}$ Bates, 433 U.S. at 378; $c f$. Virginia State Bd. of Pharmacy v. Virginia Citizens Consumer Council, 425 U.S. 748, 769 (1976) ("There is no claim that the advertising ban in any way prevents the cutting of corners by the pharmacist who is so inclined. That pharmacist is likely to cut corners in any event.").

10 See Bureau of Econ., Fed. Trade Comm'n, Effects of Restrictions on advertising and Commercial Practice in the Professions: The Gase of OpTOMETRY 25 (1980) (concluding that there is no difference in levels of quality provided by optometrists in states where advertising is permitted as compared to quality in states where advertising is outlawed) [hereinafter cited as FTC STAFF REPORT: ADvERTISING RESTRICTIONS IN OPTOMETRY]; J. CADY, RESTRICTED ADVERTISING AND COMPetition: The Case of Retail Drugs 19 (1976) (finding that there is no overall difference in quality of services provided by pharmacists in states where advertising is permitted when compared to services provided in states where advertising is banned); see also Kwoka, Advertising and the Price and Quality of Optometric Services, 74 AM. ECON. REv. 211, 215-16 (1984) (presenting findings similar to those reported in FTC STAFF REPORT: ADVERTISING RESTRICTIONS IN OPTOMETRY, supra).

${ }^{41}$ Research indicates that, at least in the case of legal clinics, advertising has actually been accompanied by an increase in the quality of legal services. See McChesney \& Muris, The Effects of Advertising on the Quality of Legal Services, 65 A.B.A. J. 1503, 1504 (1979) (finding that legal clinic that advertised rendered higher quality services than lawyers who did not advertise); Muris \& McChesney, Advertising and the Price and Quality of Legal Services: The Case for Legal Clinics, 1979 AM. B. Found. RESEARCH J. 179, 182 (stating that economic analysis of advertising indicates that "advertising will lower prices without necessarily sacrificing quality; indeed, quality may improve").

${ }^{12}$ See Darling \& Hackett, The Advertising of Fees and Services: A Study in Contrasts Between, and Similarities Among, Professional Groups, J. AdverTISING, Spring 1978, at 23, 28 (Table 2). The groups that agreed there is no correlation between promotion and competence were lawyers, accountants, dentists, and physicians. None of the groups, however, was in favor of advertising for its respective profession. 
jection of any link between advertising and quality in its first commercial speech cases comports with its rejection of similar arguments in antitrust actions against lawyers ${ }^{43}$ and engineers ${ }^{44}$ who claimed that anticompetitive restrictions in the professions were necessary to maintain quality.

The Court also recognized that quality of service is already directly regulated by licensing boards in the professions: "high professional standards . . . are guaranteed by the close regulation" to which professionals are subject. ${ }^{45}$ More importantly, any gains in professionalism from banning advertising come only by keeping consumers ignorant. In the legal profession, for example, many consumers, "particularly ... the not-quite-poor and the unknowledgeable," are kept in ignorance of lawyers' availability and so fail to assert valid legal claims. ${ }^{48}$ One might well add that even if advertising were associated with lower quality, that would not justify banning it. Consumers may quite rationally prefer lower quality at lower prices. ${ }^{47}$ Being forced to pay more for "better" services, as defined by the professions, is unlikely to strike most consumers as higher quality. The Court found that this "highly paternalistic approach" of maintaining professional standards of quality violates the first amendment. ${ }^{48}$

Finally, the Court in Bates considered and rejected a number of claims that allowing advertising by professionals would simply lead to consumer deception. Advertising, though it may provide only some of the information needed for an informed consumer choice, is not "inherently misleading." 49 In this evaluation, the majority again parted com-

Id. at 32. See also American Inst. of Certified Pub. Accountants, Report of THE SPECIAL COMMITTEe on Solicitation 11 (1981) (survey of accountants finding that a "substantial majority believes that direct uninvited solicitation does not lower quality of services performed by CPA's") [hereinafter cited as AICPA REPORT].

4 See Goldfarb v. Virginia State Bar, 421 U.S. 773, 786-87 (1975).

14 See National Soc'y of Professional Eng'rs v. United States, 435 U.S. 679, 69395 (1978).

t5 Virginia State Bd. of Pharmacy v. Virginia Citizens Consumer Council, 425 U.S. 748,768 (1976).

4 Bates, 433 U.S. at 376-77.

17 See Lanzillotti, Competition in Public Accounting: Issues and Impact, 1 GA. J. AccT. 64, 68 (1980) ("[B]uyers not only will vary the quantity and quality of service demanded, but those who purchase low quality services would pay a lower price presumably preferring that combination to a higher quality of service at a correspondingly higher price."); Muris \& McChesney, supra note 41, at 190 ("Consumers should be free to make their own price-quality tradeoffs for legal services just as they do for other purchases. If consumers freely choose lower price and lower quality rather than higher quality at higher price, this preference should be accepted as improving consumer welfare.").

48 Virginia State Bd. of Pharmacy v. Virginia Citizens Consumer Council, 425 U.S. 748, 770 (1976).

40 Bates, 433 U.S. at 372-75. 
pany with Justice Powell, who believed that lawyer advertising "inevitably will be misleading." Mo Moreover, consistent with its rejection of the more general quality arguments, the Court "view[ed] as dubious" any justification for avoiding deception that was "based on the benefits of public ignorance.?"61

If some consumers were deceived because of material omissions in advertising, "the preferred remedy is more disclosure, rather than less." 52 Thus, for example, "some limited supplementation, by way of warning or disclaimer or the like" might constitutionally be required of professionals if consumers would otherwise be misled. ${ }^{53}$ Time, place, and manner restrictions might be permissible in appropriate situations. ${ }^{64}$ If advertising was outright false, regulation to prevent associated evils would also be constitutionally permissible: "We foresee no obstacle to a State's dealing effectively with this problem." As the Court noted, states already have statutes outlawing deceptive or misleading commercial speech. $^{.56}$

The Court added, however, that any regulation of professional advertising is subject to two constitutional constraints. First, states must choose the least restrictive means of regulation: "Restrictions must be narrowly drawn, and the State lawfully may regulate only to the extent regulation furthers the State's substantial interest."

so Id. at 391 (Powell, J., dissenting).

s1 Id. at 375 (footnote omitted).

${ }^{52} I d$.

${ }^{53}$ Id. at 384.

ot See Virginia State Bd. of Pharmacy v. Virginia Citizens Consumer Council, 425 U.S. 748, 771 (1976); Bates, 433 U.S. at 384.

${ }_{65}$ Virginia State Bd. of Pharmacy v. Virginia Citizens Consumer Council, 425 U.S. 748, 771 (1976); accord Bates, 433 U.S. at 383-84. The Court has noted that none of the advertising in its commercial speech cases has involved falsity. See, e.g., Bates, 433 U.S. at 381-82.

so See Virginia State Bd. of Pharmacy v. Virginia Citizens Consumer Council, 425 U.S. 748, 771-72 (1976) (citing VA. CoDE \& 18.2-216 (1975) (current version at VA. CODE § 18.2-216 (1982))). Every state now has a statute prohibiting deceptive practices or "unfair and deceptive acts and practices." See FTC's Authority over Deceptive Advertising: Hearing Before the Subcomm. for Consumers of the Senate Comm. on Commerce, Science, and Transportation, 97th Cong., 2d Sess. 90-92 Apps A \& B (1982) (chart of statutes); see, e.g., CAL. Civ. Code § 1770 (West 1985); DeL. Code AnN. tit. 6, § 2513 (1975 \& Supp. 1984); Ga. Code. AnN. \& 10-1-372 (1985); LA. Rev. Stat. ANN. § 411 (West 1985); Mass. ANn. Laws ch. 93A, § 2 (Michie/Law. Co-op 1985); Mo. ANN. STAT. § 570.160 (Vernon 1985); N.Y. GEN Bus. Law § 349 (McKinney Supp. 1984); OhIo Rev. Code ANN. § 1345.02 (Page 1979 \& Supp. 1984); PA. Stat. AnN. tit. 73, \& 201-3 (Purdon $1971 \&$ Supp. 1985). These statutes are often known as "UDAP" statutes or "Little FTC Acts," because the relevant language derives from section 5 of the Federal Trade Commission Act, 15 U.S.C. $\S 45$ (1982).

${ }^{67}$ In re R.M.J., 455 U.S. 191, 203 (1982); accord Zauderer, 105 S. Ct. at 2275 ("Commercial speech that is not false or deceptive and does not concern unlawful activ- 
view of the admitted benefits of advertising and consumers' constitutional right to receive it, any such regulation could not extend as far as a ban. According to the Court, "What is at issue is whether a State may completely suppress the dissemination of concededly truthful information about entirely lawful activity, fearful of that information's effect upon its disseminators and its recipients. ... [W]e conclude that the answer . . . is in the negative."

One argument offered by professionals in favor of total bans has been the difficulty of enforcing more limited restrictions designed to avoid consumer deception or falsity. ${ }^{58}$ Because the number of professionals selling services is so large, it has been urged that prior restraint is the only realistic form of regulation. The Court rejected this argument in Bates. Reasoning that the extent and consequently the costs of any deception that a ban might avoid paled beside the benefits of advertising, the Court suspected that

most lawyers will behave as they always have . . . . For every attorney who overreaches through advertising, there will be thousands of others who will be candid and honest and straightforward. And, of course, it will be in the latter's interest, as in other cases of misconduct at the bar, to assist in weeding out those few who abuse their trust. ${ }^{60}$

More recently, the Court has rejected the related arguments that it is intrinsically difficult to distinguish deceptive legal advertisements from truthful ones and that making this distinction is more difficult for legal services than for other products. ${ }^{61}$

In short, a state is free to impose reasonable regulations to avoid genuine problems but may not ban advertising altogether. A regulation will be deemed unreasonable if a less restrictive alternative exists. The Court applied this approach in In re R.M.J. ${ }^{62}$ to evaluate the constitutionality of a state restriction that limited the groups to whom a lawyer could send professional announcement cards. Because the state gave no

ities . . . may be restricted only in the service of a substantial governmental interest .....").

s8 Virginia State Bd. of Pharmacy v. Virginia Citizens Consumer Council, 425 U.S. 748, 773 (1976); accord Zauderer, 105 S. Ct. at 2275 (1985) ("[B]lanket bans on price advertising by attorneys and rules preventing attorneys from using nondeceptive terminology to describe their fields of practice are impermissible.").

so See Bates, 433 U.S. at 379.

${ }^{60}$ Id.

61 See Zauderer, 105 S. Ct. at 2279. The Court also noted that its views are shared by both the American Bar Association and the Federal Trade Commission. See id. at 2279 n.13.

62 455 U.S. 191 (1982). 
reason for its restriction, the Court surmised that the difficulty of supervising the sorts of material lawyers would send accounted for the restriction. If so, the Court said, a prohibition on sending announcement cards to some groups was apparently more drastic than necessary to advance any legitimate state goal. "For example, by requiring a filing with the Advisory Committee of a copy of all general mailings, the State may be able to exercise reasonable supervision over such mailings. There is no indication in the record of a failed effort to proceed along such a less restrictive path." ${ }^{\prime 3}$ Because a less restrictive alternative to a total ban on sending cards to some groups was available but not tried, the ban was unconstitutional.

The Court reaffirmed this approach ${ }^{84}$ in Zauderer, in which it considered constitutional challenges to several separate restrictions on lawyer advertising, including a ban on illustrations in advertisements. Zauderer, an attorney, placed an advertisement in various newspapers informing readers of the dangers of the Dalkon Shield Intrauterine Device and expressing his willingness to handle legal actions against the Shield's manufacturer. ${ }^{65}$ The advertisement included a picture of the Shield, which the Court noted was accurate. ${ }^{68}$ The Court held that the state's rule prohibiting the use of illustrations in legal advertisements could not stand because the state could police the use of misleading illustrations on a case-by-case basis. ${ }^{67}$ Furthermore, Zauderer and In re R.M.J. both indicate that the burden of justifying promotional restrictions is on the state bar that imposes them. ${ }^{68}$ In commercial speech

6s Id. at 206 (footnotes omitted).

64 The Court has reemphasized the less-restrictive-alternative requirement in other commercial speech cases not involving restraints on promotion in the professions. For an application of the test that a restraint on commercial speech be "not more extensive than necessary," see Bolger v. Youngs Drug Prods., 463 U.S. 60, 69 (1983) (citing Central Hudson Gas \& Elec. v. Public Serv. Comm'n, 447 U.S. 557, 566 (1980)). The requirement of less restrictive alternatives to bans on commercial speech parallels the identical first amendment principle for political speech. See Reich, Preventing Deception in Commercial Speech, 54 N.Y.U. L. REv. 775, 784 \& n.56 (1979) (citing cases).

6s See Zauderer, 105 S. Ct. at 2271-72.

${ }^{66}$ See id. at 2279.

${ }^{67}$ See id. at 2281 . The state had contended that prior restraints against illustrations in advertisements were justified because the effects of illustrations were "subconscious" and so deception would be difficult to detect. Id. at 2280-81. Citing the success of the Federal Trade Commission in policing illustrations used in advertising on a caseby-case basis, the Court found that the prophylatic approach taken by the state could not stand. Id. at 2281. However, the Court upheld disciplinary sanctions against Zauderer for failing to include in his advertisement information alleged by the bar to be necessary to avoid deception. See id. at 2281-82; infra note 240.

${ }^{68}$ See Zauderer, 105 S. Ct. at 2277 (Where advertisements are not false or deceptive, "our decisions impose on the State the burden of establishing that prohibiting the use of such statements to solicit or obtain legal business directly advances a substantial governmental interest."); In re R.M.J., 455 U.S. at 203 ("Even when a communication 
cases not involving professionals, the Court has similarly emphasized that "[t]he party seeking to uphold a restriction on commercial speech carries the burden of justifying it."

In summary, the Supreme Court's analysis of advertising demonstrates its awareness of both the benefits and possible costs of advertising, and provides a standard for state regulation based on their relative weights. The benefits include provision of greater information to consumers and furtherance of competition in the market for professional services. On the cost side, the Court does not believe, as professional associations have alleged, that advertising results in a decline in quality. Consumer deception and false advertising are possible, though their likelihood and magnitude are thought to be slight. In light of its analysis, the Court leaves a state free to regulate, but the burden of showing that regulations are narrowly drawn to address particular problems remains on the state. Regulation in any event cannot extend to outright bans on advertising.

\section{B. Nonadvertising Promotion}

When the Court turns to nonadvertising forms of promotion by professionals, the difference in the analysis is striking. Whether the issue is solicitation by lawyers or use of trade names by optometrists, the Court abandons the analytical framework developed in the commercial speech cases involving advertising. The Court does not even attempt to discuss benefits. Moreover, the test applied to measure the importance of costs, especially deception, is much less rigorous than that found in the advertising cases.

\section{Benefits}

An initial difference between the advertising and nonadvertising lines of cases is the Court's unwillingness to recognize the benefits of nonadvertising promotion. In Friedman $v$. Rogers, ${ }^{70}$ the Court simply stated that trade names had only "ill-defined associations" with useful

is not misleading, .... the State must assert a substantial interest and the interference with speech must be in proportion to the interest served.").

${ }_{62}$ Bolger v. Youngs Drug Prods., 463 U.S. 60, 71 n.20 (1983) (citing cases). For a clear misinterpretation of this requirement, see Princess Sea Indus. v. Nevada, 97 Nev. 534, 536, 635 P.2d 281, 283 (1981) (upholding the state legislature's ban on advertising of prostitution, even though prostitution itself was legal, because an "act of legislature is presumed to be constitutional") (quoting State ex rel. Tidvall v. District Court, 91 Nev. 520, 526, 539 P.2d 456, 460 (1975)), cert. denied, 456 U.S. 926 (1982).

70440 U.S. 1 (1979). 
information. ${ }^{71}$ This position elicited a vigorous dissent from Justice Blackmun, who recognized the importance of trade names in conveying various types of information to consumers. ${ }^{72}$ Later commentators have been similarly unimpressed by the Friedman majority's claim that trade names have little or no informational value. ${ }^{73}$ The availability of trade names is generally seen as an important incentive to sellers to invest in providing valuable information. ${ }^{74}$

Ohralik v. Ohio State Bar ${ }^{75}$ is likewise notable for the Court's refusal to admit that another nonadvertising form of promotion-commercial solicitation-can be beneficial. But again, commentators have noted that solicitation may offer considerable benefits to consumers, even more than advertising does. ${ }^{76}$ Ohralik's own solicitation, in fact, considerably benefitted the two women solicited, who had been injured in a car accident. Without the solicitation, they would have been unaware of an insurance policy under which they eventually ob-

71 Id. at 12.

${ }^{72}$ See id. at 20-23 (Blackmun, J., concurring in part and dissenting in part).

${ }^{73}$ See, Andrews, supra note 11, at 980 . Reich observes that

trademarks and names give sellers an incentive to invest in quality control and promotion, to the extent that consumers are willing to pay a premium for avoiding more costly means of discovering the goods and services they want. Marks and names become valuable business assets precisely because, and to the extent that, they are an inexpensive and efficient source of product information for consumers.

Reich, supra note 64 , at 795-96.

74 According to one commentator:

[A] brand name is used to identify a product and thereby link information to that product. This link between information and product is perfected by the use of a trademark, for the trademark proprietor has the exclusive right to use the mark for his product. In this way the trademark property rights system enables investments in brand name by assuring that others, being denied any representation by that name, cannot usefully capture returns from those investments. A seller is generally subject to less freeriding on his advertising and sales efforts, and therefore has less difficulty in capturing the gains to whatever investments he makes in increased quality and brand name, when these efforts are made specific to his mark. If, to the contrary, consumers cannot make the link from product to information clearly, then information investments yield less appropriable returns, [and] the amount of information supplied is reduced . . . .

Krouse, Brand Name as a Barrier to Entry: The ReaLemon Case, 51 S. Econ. J. 495, 497-98 (1984).

75436 U.S. 447 (1978).

${ }^{78}$ See Murdock \& Pattison, Solicitation and the Legal Profession: A New Issue for Consumer Affairs Professionals, 18 J. Consumer AfF. 266, 283 (1984) ("One-toone communications may provide more real benefits than general advertising to the prospective consumer of legal services. Among other reasons, such direct communications can be tailored to particular situations and clients, and they can thus do a better job of imparting information to a lay audience."). 
tained recovery. ${ }^{77}$ Never admitting that the solicitation was actually beneficial, the Court disingenuously noted that if any benefits actually accrued, the state's ban against solicitation did not "prohibit a lawyer from giving unsolicited legal advice; it proscribes the acceptance of employment resulting from such advice."78 Allowing the women to benefit from the lawyer's skill and time without paying for the benefit received was apparently of no concern to the Court. The Court's attitude was also completely inconsistent with its recognition that Ohralik's approach to the two women was from the start a business proposition. ${ }^{79}$ If no prospect of mutual gain to lawyer and client was foreseeable, then the attorney had no incentive to communicate the information in the first place. In a similar situation in the future, the information would simply not be volunteered.

Just as Ohralik and Friedman missed the informational benefits of nonadvertising promotion, so did they ignore the competitive benefits of such commercial speech. Logically, one would think, the Court would consider whether the various competitive benefits discussed in the advertising cases-lower prices and easier entry for less established professionals-might also be available from nonadvertising promotion. These questions were never raised, however. ${ }^{80}$

In Friedman, the Court had to go out of its way to avoid the competitive aspects of the promotional ban in question. The challenged ban on the use of trade names by optometrists was part of an attempt by "professional" optometrists to put at a competitive disadvantage their "commercial" rivals doing business in state-wide chain stores under a single name. The promotional restriction was actually part of an all-out political and regulatory war against competition and for control of the profession. ${ }^{81}$ The Court frankly recognized this conflict, ${ }^{82}$ yet

77 In various conversations with the two injured women and the family of one of them, Ohralik explained the consequences of being subject to the state's guest statute, and of being struck by an uninsured motorist. He discovered an uninsured motorist clause in an insurance policy, the existence or importance of which was unknown to the injured women and their families, and under which at least one woman eventually recovered the full policy amount. Ohralik, 436 U.S. at 450 . These events all occurred during Ohralik's solicitation of the women, before they signed his contingency fee agreement. See id. at 449-52.

${ }^{78}$ Id. at 458.

70 See id. at 457.

80 In his Ohralik concurrence, Justice Marshall did express some misgivings about the competitive effects of banning solicitation: "IT]he Disciplinary Rules against solicitation fall most heavily on those attorneys engaged in a single-practitioner or small-partnership form of practice-attorneys who typically earn less than their fellow practitioners in larger, corporate-oriented firms." Id. at 475 (Marshall, J., concurring) (footnote and citation omitted).

81 The Texas Optometry Act, Tex. Civ. Stat. AnN. art. 4552 (Vernon 1969) (current version at TEx. Civ. STAT. ANN. art. 4552 (Vernon 1976 \& Supp. 1985)), 
failed to acknowledge the deleterious effects of the trade-name ban on chain-store optometrists which, like chain stores generally, rely on brand-name identification to ensure repeat sales and so competitive survival. ${ }^{83}$ Although such competitive concerns were of considerable importance in the advertising cases, they went completely undiscussed in the nonadvertising cases.

Thus, consideration of the principal benefits discussed in the advertising cases-increased information and enhanced competition-was missing from the analysis in the nonadvertising cases. In addition, other factors perceived as benefits of advertising were treated as costs in the nonadvertising cases. For example, if advertising increased the amount of litigation, that result merely indicated to the Court that some legitimate suits were not being brought without advertising. ${ }^{84}$ In Ohralik, on the other hand, "stirring up litigation" was one of the "substantive evils of solicitation," ginia State Board of Pharmacy v. Virginia Citizens Consumer Coun$\mathrm{cil}^{86}$ and Bates the Court had rejected the position that promotion compromises professionalism, ${ }^{87}$ the Ohralik Court found that solicitation could erode the professionalism of attorneys. ${ }^{88}$ Why advertising and solicitation produced diametrically opposite results was not explained. Finally, in Ohralik, solicitation was criticized because it "may distress the solicited individual." mitted even though it may be "tasteless and excessive" sive."91 No attempt has been made to explain why it is constitutionally

that banned the use of trade names was enforced by the state Optometry Board. Four of the six members of the Optometry Board had to be members of the Texas Optometric Association, the group of "professional" optometrists opposed to the use of trade names. See Friedman, 440 U.S. at 5-6. The Optometry Board itself was established by legislation advocated by the "professionals" after the "commercial" optometrists obtained control of the old State Board of Examiners, which regulated entry into the profession. See id. at 17-18. The Optometry Act replaced the Board of Examiners with the Optometry Board, see id. at 3, restoring governance of the industry to the "professional" camp.

${ }^{82}$ Friedman, 440 U.S. at 5 ("The dispute in this case grows out of the schism between 'professional' and 'commercial' optometrists in Texas.").

${ }^{83}$ See Klein \& Leffler, The Role of Market Forces in Assuring Contractual Performance, 89 J. PoL. EcoN. 615, 616 (1981).

s4 See Bates, 433 U.S. at 376; supra notes $25-26$ and accompanying text.

${ }^{85}$ Ohralik, 436 U.S. at 461.

8 se 425 U.S. 748 (1976).

87 See Bates, 433 U.S. at 368; Virginia Pharmacy, 425 U.S. at 769-70; supra text accompanying notes $37-38$.

${ }_{88}$ See Ohralik, 436 U.S. at 461 \& n.19.

89 Id, at 465.

so See Virginia Pharmacy, 425 U.S. at 765.

91 See Zauderer, $105 \mathrm{~S}$. Ct. at 2280 . In commercial speech cases not involving professionals, the Court has said that, where obscenity was not involved, "we have 
relevant that nonadvertising professional speech may be distressful, when it is irrelevant that professional advertising may be tasteless, excessive, or offensive.

\section{Costs}

Although the Court found that solicitation could cause losses in professionalism, detrimental stirring up of litigation, and distress to some individuals, these were not solicitation's principal costs. In both Ohralik and Friedman, the Court was more concerned with the possibility of deception. In neither case did the Court indicate that any harmful deception had actually arisen from the particular professionals' actions. ${ }^{92}$ But the Court deemed substantial the possibility of harm to other consumers from the challenged practices. According to the Court, "aspects of solicitation" included "fraud, undue influence, intimidation, overreaching, and other forms of 'vexatious conduct." "'ss Similarly, according to the Court, the use of trade names "enhances the opportunity for misleading practices."

Particularly noteworthy in the Court's discussion of deception was its apparent abandonment of a burden on the state to show a significant chance of actual harm to consumers from possibly deceptive practices. ${ }^{95}$ For example, it was enough in Ohralik for the state to claim that solicitation was "as likely as not to discourage persons needing counsel from

consistently held that the fact that protected speech may be offensive to some does not justify its suppression." Bolger v. Youngs Drug Prods., 463 U.S. 60, 71 (1983) (quoting Carey v. Population Servs. Int'l, 431 U.S. 678, 701 (1977)).

92 In Ohralik, the Court dwelt on the unsavory use of a hidden tape-recorder by the attorney at the initial interviews with his two clients. There was, however, no suggestion that this practice caused the clients any harm. The purpose of the tape was apparently to guard against the risk of attempted breach of contract by his clients-a risk the attorney was quite correct in anticipating. See Ohralik, 436 U.S. at 451-52.

9s Id. at 462. The Court also condemned solicitation because it "may exert pressure" on consumers. Id. at 457. The Court, however, did not define "pressure," "overreaching" or "vexatious conduct." Professor Craswell notes that although the Federal Trade Commission and the Supreme Court have attacked "high-pressure" sales, their reasons for doing so remain obscure. "[I]n spite of this unanimous condemnation of high-pressure sales . . . none of these authorities has been able to articulate the reasons for the condemnation." Craswell, The Identification of Unfair Acts and Practices by the Federal Trade Commission, 1981 WIs. L. REv. 107, 146. "High pressure" and "overreaching" are not discussed here separately from deception. The remedies for possible deception that are discussed in Section III would also cure putative problems of "high pressure" and "overreaching." See infra text accompanying notes 260-73.

- Friedman, 440 U.S. at 15.

os In Zauderer, by comparison, the Court rejected the state's argument that potential deception justified a ban on illustrations in advertisements: "The States's arguments amount to little more than unsupported assertions" devoid of "any evidence or authority of any kind." Zauderer, 105 S. Ct. at 2281. 
engaging in a critical comparison . . . of legal services." ${ }^{\text {96 }}$ It sufficed that a lawyer who solicited "may be inclined" to subordinate client interest to his own. ${ }^{97}$ Such "lapses of judgment can occur in any legal representation, but we cannot say that [solicitation] does not create special problems of conflict of interest." 98 The Court did point to the record of "detrimental aspects of face-to-face selling" compiled by the Federal Trade Commission as justifying the ban on lawyer solicitation; ${ }^{99}$ but that record was assembled for the Commission's rulemaking covering door-to-door sales and had nothing to do with the selling of legal services. ${ }^{100}$ All in all, as one commentator has noted, "the Ohralik Court substantially lowered the state's burden of proof in justifying its restrictions on solicitation."101 The same was true in Friedman, in which the Court contented itself with constructing hypothetical problems that created a "significant possibility that trade names will be used to mislead," though none of the supposed problems listed had actually occurred in the case. ${ }^{102}$

The Court itself has not recognized the inconsistent ways it has imposed the burden of proving deception in the nonadvertising and advertising cases. In Zauderer the Court contended, "Our recent decisions involving commercial speech have been grounded in the faith that the free flow of commercial information is valuable enough to justify imposing on would-be regulators the costs of distinguishing the truthful from the false, the helpful from the misleading, and the harmless from the harmful." 103 This statement is simply untrue. The Court's decisions concerning solicitation and trade names have clearly imposed no burden on the states to distinguish beneficial from baleful commercial speech.

Not only did the Court relax a state's burden of proving deception in the nonadvertising cases, it also departed from two fundamental principles it had earlier laid down for remedying any deception. First, the Court was tolerant of a state's curing alleged deception by com-

Ohralik, 436 U.S. at $457-58$.

97 Id. at 461 n.19.

88 Id.

${ }_{89}$ Id. at 464-65.

${ }^{100}$ See Cooling-Off Period for Door-to-Door Sales: Trade Regulations Rule and Statement of Basis of Purpose, 37 Fed. Reg. 22,934, 22,937 (1972) (codified at 16 C.F.R. $\S 429.1$ (1985)) [hereinafter FTC: Cooling-Off Period]; infra text accompanying note 108 .

${ }^{101}$ Note, Time, Place, or Manner Restrictions on Commercial Speech, 52 GEo. WASH. L. REv. 127, 136 (1983).

${ }^{102}$ Friedman, 440 U.S. at 13. "The prohibition in Friedman was a total ban on a business practice or form of advertising because of the potential for deception . . . " Jay Norris, Inc. v. FTC, 598 F.2d 1244, 1252 (2d Cir.) (emphasis added), cert. denied, 444 U.S. 980 (1979).

${ }^{103}$ Zauderer, 105 S. Ct. at 2279-80. 
pletely banning the commercial speech in question. This remedy was the one that was specifically denied to the states in the advertising cases. In Ohralik, the Court sought to distinguish the advertising cases:

Unlike the advertising in Bates, in-person solicitation is not visible or otherwise open to public scrutiny. . . . If appellant's view were sustained, in-person solicitation would be virtually immune to effective oversight and regulation by the State or by the legal profession . . . . It therefore is not unreasonable, or violative of the Constitution, for a State to respond with what in effect is a prophylactic rule. ${ }^{104}$

This analysis misreads Bates. In that case, as discussed above, the Court rejected the enforcement argument, not because advertising abuses were easily detectable, but because the Court doubted that widespread abuses were likely to occur in the first place. ${ }^{105}$ Consistent with its distaste for comparing solicitation's costs and benefits, the Court in Ohralik refrained from posing what logically ought to have been the first question: is there reason to believe that deception will be a significant problem? If not, enforcement problems are largely moot.

This criticism does not necessarily deny that differences between advertising and other forms of promotion may ultimately make a total ban necessary. Upon finding that deception costs outweigh the benefits of the speech in question, states perhaps should enact a ban if they are unable to mitigate deception through lesser restrictions that preserve the benefits of commercial speech. But the Court, in its second departure from the discussion of permissible remedies in the advertising cases, allowed bans on nonadvertising promotion to stand without considering whether less restrictive alternatives were available to combat deception. One commentator has recognized that "[ $\mathrm{t}] \mathrm{he}$ problem with the analysis is that the Ohralik Court did not expressly consider whether the state could prevent deception and overreaching equally well by means of a less restrictive rule."108 The same must be said of Friedman. ${ }^{107}$ The Ohralik Court's citation to the FTG rulemaking on door-to-door selling as justification for a solicitation ban was particu-

104 Ohralik, 436 U.S. at 466-67 (footnote omitted).

105 See Bates, 433 U.S at 379; supra text accompanying notes 59-61.

${ }^{108}$ Reich, supra note 64, at 789; cf. Note, supra note 101, at 136 ("Although the [Ohralik] Court did not fully explain its method of inquiry, it clearly did not require that the manner restriction be narrowly tailored to serve the asserted significant interest .....").

107 Reich, supra note 64, at 790 (noting that as in Ohralik, the majority in Friedman "declined to consider whether the state had less restrictive means of preventing deception"). For a discussion of less restrictive alternatives to avoid deception in connection with the use of trade names, see Andrews, supra note 11, at 981 . 
larly anomalous. Despite finding instances of actual deception, the FTC did not ban door-to-door solicitation but only promulgated certain additional contractual remedies to address perceived problems. ${ }^{108} \mathrm{Fi}-$ nally, in neither Ohralik nor Friedman did the Court take note of the fact that licensing boards (including bar associations) supposedly regulate and enforce the quality of services provided-a point the Court did make in its advertising decisions.

In the nonadvertising cases, then, the Court has abandoned the cost-benefit apparatus for analyzing commercial speech that it carefully crafted in the advertising cases. Benefits of information and enhanced competition need not be weighed against costs of deception. Restrictions on speech need not be tailored to specific problems. Instead, entire forms of commercial speech may be outlawed if deception, alleged but unproved, may arise. Juxtaposing the advertising with the nonadvertising cases demonstrates fundamental inconsistencies in analyzing commercial speech in the professions; "the standards for evaluating government claims that particular commercial speech is misleading remain open-ended. The standards are searching and skeptical when pharmacist and lawyer advertising are at issue; they are lax and trusting when optometrist trade names are in question."109

The tension between the advertising and nonadvertising cases is particularly obvious in the consideration of deception. In advertising cases, even if the state can demonstrate actual deception, it must use more circumscribed regulation than outright prohibitions to mitigate the problem. Yet total bans on nonadvertising speech are constitutionally permissible merely to prevent possible deception-no actual deception need be shown. As a practical matter, this rule leaves the door open for states to ban solicitation and other nonadvertising speech merely by reciting the possibility of deception, whatever its true likelihood and extent. The result is constitutional tolerance of prior restraints on speech to prevent possible deception, though no deception was present in the cases themselves and the extent of deception generally was unknown.

The ease with which the states have succeeded in defending bans on nonadvertising speech suggests that solicitation, trade names and other nonadvertising promotion are simply unimportant, or even personally abhorrent to the Court. ${ }^{110}$ In this view, the Court reflects the

${ }^{108}$ See FTC: Cooling-Off Period, supra note 100, at 22,934 (allowing the buyer three days in which to cancel certain door-to-door transactions).

109 Shiffrin, supra note 9, at 1221 (footnotes omitted).

110 Chief Justice Burger makes no secret of his distaste for lawyers' promotion. During his annual report to the American Bar Association in February, 1984, "the 
apparent opinion of the organized bar, which consistently underestimates the importance of promotional restrictions to the average practitioner. ${ }^{111}$ The Court's schizophrenic opinions are codified in the distinction between advertising and nonadvertising promotion in the ABA's new Model Rules. ${ }^{112}$

In short, both bench and bar now tolerate advertising as the traditional means of informing consumers in a free-market economy but regard other means of promotion as plagued by deception and lacking in

chief justice chastised lawyers for 'using the same modes of advertising as other commodities, from mustard, cosmetics and laxatives to used cars,' and questioned whether the profession's 'Iow public standing' derives in part 'from the insistence of some lawyers on exercising their First Amendment rights to the utmost." "Middleton, Ads Pay Off-In Image and Income, Nat. L. J., March 5, 1984, at 1, col. 1, 22, col. 4. Chief Justice Burger's address is reprinted in Burger, The State of Justice, A.B.A. J., April, 1984 , at 62 . Chief Justice Burger reiterated his criticism of advertising by lawyers at the 1985 annual meeting of the American Bar Association. During his remarks, he termed some advertising by lawyers "sheer shysterism" and asserted that he would "dig ditches" before placing an advertisement were he still practicing law. See Burger Criticism Prompts Defense of Lawyer Ads, N.Y. Times, July 9, 1985, at A10, col. 2.

111 "[T] wagon. And many-mostly those in large corporate firms-consider it distasteful and unprofessional and are highly unlikely to be seen in a television commercial trying to attract business." Middleton, supra note 110, at 22, col. 4. Robert Kutak, chairman of the ABA's Commission on Evaluation of Professional Standards, claimed that promotional restrictions are a "less important" matter for any bar code of self-regulation and ethics, and that lawyers generally agree with this assessment. See Kutak, Model Rules of Professional Conduct: Why Do We Need Them?, 36 OkLA. L. REv. 311, 311-12 (1983). The actual enforcement of the ABA's Code of Professional Responsibility and state canons of ethics or codes of professional responsibility indicates just the reverse-that promotion is the single biggest issue arising under the bars' ethical rules. Some $60 \%$ of ABA and state bar ethics opinions have concerned prohibition or allowance of various types of promotion. See Morgan, The Evolving Concept of Professional Responsibility, 90 HaRv. L. Rev. 702, 712 (1977) (citing O. MARU, Digest of STATE BAR ETHICs Opinions 7-9 (1967)). Over a 20 year period, 80\% of the opinions of the Ethics Committee of the State Bar of Texas concerned promotion. See Schuchman, Ethics and Legal Ethics: The Propriety of the Canons as a Group Moral Code, 37 Geo. Wash. L. Rev. 244, 255-56 (1968) (citing Smith, The Texas Canons of Ethics Revisited, 18 BaYlor L. Rev. 183, 192-93 (1966)).

112 See Model Rules of Professional Conduct Rule 7.2 (1983) (generally permitting advertising that is not false or misleading); $i d$. Rule 7.3 (generally outlawing solicitation). One lawyer who reviewed the $A B A$ 's reasons for continuing to ban solicitation has written:

[T] ]he ABA's stated concerns are baloney. . . .

. . [T] [Te ABA's antisolicitation rule is a joke. Unfortunately, since the $\mathrm{ABA}$ personifies all lawyers in the minds of many, it's a joke on all of us, and the sort of thing that contributes to the steady decline in the prestige of lawyers in this country. The American public knows a shyster when it sees one, and the ABA's articulated positions on this subject . . . have been obviously protectionist and inherently unpersuasive.

Sims, Lawyers' Antitrust Blanket Wears Thin, Legal Times, Oct. 15, 1984, at 14, col. 4, 19 col. 2. 
countervailing benefits. ${ }^{113}$ The "commercial speech doctrine" turns out to be rather more limited than the name suggests, at least as applied to the professions. Only advertising receives any measure of first amendment protection. Nonadvertising forms of promotion have been largely unaffected by the development of the doctrine.

\section{AN INTEgRated MODEL OF Restrictions ON CoMmercial SPEECH}

This section analyzes the distinctions among forms of promotion drawn by the Supreme Court in its commercial speech cases. After a brief survey of the use of advertising versus other promotional techniques, an economic model of promotional restrictions is constructed to analyze the sorts of bans found in the professions. The discussion concentrates on the legal profession, but other professions are also considered. The model is particularly useful for evaluating two benefits of promotion omitted from the Court's analysis of nonadvertising techniques: consumer information and competition. It is less helpful in addressing the deception problem, which is thus considered separately in Section III. Ignoring the deception issue, the model indicates that there is no principled reason for treating solicitation or the use of trade names differently from advertising. The informative and competitive effects of both can be analyzed identically. Indeed, one principal conclusion from the model is that the adverse information and competition effects of promotional bans-those effects that so impressed the Court in its advertising cases-are actually greater in the case of bans on nonadvertising promotion.

\section{A. Advertising and Other Promotional Techniques}

To be profitable and so to survive, firms must not only produce goods or services, they must sell them. In any firm, then, marketing or promotion is a function distinct from, but no less important than, pro-

113 In regulating promotional practices that have not yet been considered by the Supreme Court, states distinguish between permissible and impermissible activities according to whether they look "more like" advertising or solicitation. One state's regulations against direct mail advertising have been declared unconstitutionally vague because the court could not determine how to draw the line between elements of advertising (permissible under the state's regulations) and elements of solicitation (impermissible) in direct mail. See Spencer v. Honorable Justices of Supreme Court of Pennsylvania, 579 F. Supp. 880 (E.D. Pa. 1984). For a summary of other cases, see Whitman \& Stoltenberg, Direct Mail Advertising by Lawyers, 45 U. PrTT. L. Rev. 381 (1984). 
duction. ${ }^{114}$ The distinction between production and promotion is particularly evident in service industries like law, in which there is no production for inventory storage and later sale. ${ }^{115}$ For the law firm to survive, lawyers must woo clients to the firm before production can take place. Thus, firms hire some lawyers, not to produce legal services for clients, but to specialize as "rain-makers" in attracting clients.

In fact, the very form of law partnerships reflects the need for promotion:

In law firms, it is only the partners who participate in profit sharing. Associates typically are paid a "straight salary" that is not a function of firm profits. Accession to partner status from the associate ranks is to a large extent a function of existing partners' perception of an associate's ability to bring in business .....

.. . Even after he becomes a partner, a lawyer's share of the profits may not yield an income in excess of his salary as an associate. Only with the generation of new business does a partner become more than a slight sharer in profits. His ultimate share depends on the contributions to firm profits that the partner makes by attracting clients to the firm ....116

Lawyers need only open the American Bar Association Journal for tips on how to win clients. ${ }^{117}$ Comparable publications for other profes-

114 For a general analysis of different functions performed within a single firm, see Stigler, The Division of Labor is Limited by the Extent of the Market, $59 \mathrm{~J}$. PoL. Econ. 185 (1951), reprinted in READINGS IN Microeconomics 140 (W. Breit \& H. Hochman eds. 1971).

118 For a discussion of the importance of the distinction between production and promotion of services by law firms, see McChesney, Team Production, Monitoring, and Profit Sharing in Law Firms: An Alternative Hypothesis, 11 J. LEGAL STUD. 379 (1982).

11 Id. at 391-92 (footnotes omitted).

117 For example, two writers have commented that

[w] hat rainmakers do so well is move a conversation with a prospective client quickly to the next step: setting a date for a meeting . . . A lawyer can request the person's business card and offer to make a followup call or can suggest to "get together next Monday" without crossing the ethical line into solicitation.

Smock \& Heintz, Attracting Clients with Marketing, 69 A.B.A. J. 1432, 1434 (1983). See also Foonberg, How a Small Firm Can Get and Keep Clients, A.B.A. J., June 1984, at 50; Goldblatt, Rainmaking with a Firm Newsletter, A.B.A. J., June 1984, at 54; Morgan, How Small Firms Can Attract Corporate Litigation, A.B.A. J., Oct. 1984, at 59; Winter, The Fine Art of Rainmaking, A.B.A. J., Oct. 1984, at 54. The marketing literature provides similar information. See Kotler \& Connor, Marketing Professional Services, J. Marketing, Jan. 1977, at 71. 
sions convey similarly practical information on how to generate business. $^{118}$

The need to promote as well as to produce causes particular problems for the smaller professional firm, in which specialization in promotion is achieved only at a greater cost in lost specialization in production. ${ }^{110}$ Consider, for example, the difficulties faced by the sole practitioner in law, who may lose new business simply by being out of the office when new clients come knocking. ${ }^{120}$ The experience of one sole practitioner demonstrates the frustration of trying simultaneously to produce and to promote legal work. When asked what problems he had in starting his practice, he replied, "Getting business. This is a great profession if someone is feeding you business. You can't get business and work at the law at the same time--you can't do both, you'd be on the go 24 hours a day if you'd do that."121 In larger firms, lawyers

118 Doctors, for example, can read about "Marketing Tools," see D. MACKIE \& D. Decker, Group and IPA HMOs 177 (1981), or about "How to Gain and Retain Patients," see J. Eisenberg, S. Williams \& E. Smith, The Physician's Practice 33 (1980).

11 See Stigler, reprinted in READINGs IN Microeconomics, supra note 114, at 144 (discussing the problems created by the firm's undertaking "rival" functions, that is, those functions for which "the greater the rate of output of one process, the higher the cost of a given rate of output of the other process"). Stigler remarks that a particular problem arises "when the entrepreneur must neglect production in order to supervise marketing." Id. at 142. Frank Knight was perhaps the first to note that specialization in promotion is efficient. See F. KNIGHT, RISK UNCERTAINTY AND PROFIT 25557 (1971) (originally published 1921). More recently, Alchian has noted that "like any other production activity, specialization in information is efficient. Gathering and disseminating information about goods or about oneself is in some circumstances more efficiently done while the good or person is . . . able to specialize (i.e., while specializing) in the production of information." Alchian, Information Costs, Pricing, and Resource Unemployment, 7 W. ECON. J. 109, 110 (1969). For a discussion of the gains to lawyers from specialization, see M. Friedman \& S. KuzNETS, INCOME FROM INDEpendent Professional Practice 31 (1945).

120 One commentator has written:

A . . . problem for sole practitioners or very small firms is the risk that no attorney will be available when a prospective client attempts to contact them ... The availability of an attorney or partner to whom the client can speak may sometimes prevent the loss of the client. The same reasoning applies when an attorney plans to take a vacation. Some of his clients will need legal counsel while he is away, and he can be more confident that he will not "lose" these clients to a partner than he can be that he will not lose them to another firm or sole practitioners whom they may retain in his absence.

S. Silberman, The Market, The Firm and Delivery of Legal Services 97-98 (1975) (unpublished Ph.D. dissertation, Yale University). The truth of Silberman's description is evident from the following quotation from a sole practitioner: "I saw another client, an insurance agent. . . . He told me I lost a beautiful personal injury case while I was away - a little boy was injured. I told him a lawyer needs a vacation-but that made me feel bad to lose it." J. Carlin, LAwYers on Their OwN 78 (1962).

121 J. Carlin, supra note 120 , at 169. 
carry out the two functions of obtaining and producing work more independently. The gains from specialization in producing legal services need not be sacrificed by the need for promotion, which is itself susceptible of specialization in the hands of other lawyers.

Clients as well as lawyers value promotion, of course. Indeed, lawyers value promotion only because it satisfies potential clients' demands for such information as services available, price schedules and office locations. Advertising is only one of several means of promotion that can provide this information. Other techniques observed in the various markets for professional services include solicitation (or "personal selling," as it is often called), the use of trade names, and the payment of referral fees. ${ }^{122}$ Analytically, each of these promotional techniques has much in common. ${ }^{123}$ Each technique promotes the seller's own commercial gain, which the seller achieves by imparting valuable information to consumers. ${ }^{124}$ Each substitutes for a potentially more costly consumer search for information about sellers' fees, specialties, locations and other characteristics. ${ }^{125}$ Thus, each promotional technique poten-

122 See Sims, supra note 12, at 11, col. 2 ("[A]dvertising is just one form of solicitation, as are mass mailings, golf outings, club memberships, political activities, and ambulance chasing.").

${ }^{123}$ In Spencer v. Honorable Justices of the Supreme Court, 579 F. Supp. 880 (E.D. Pa. 1984), the court noted that although ethical rules drew a sharp distinction between advertising and solicitation, the bar was unable to explain the difference between the two:

Whereas DR 2-101(A) permits lawyers to advertise as long as it is not false or misleading, DR 2-103(A) and DR 2-104(A) prohibit all lawyer self-recommendation and solicitation. Nowhere are the terms "advertising," "recommendation" or "solicitation" defined and, further, the body charged with the responsibility for creating, interpreting, and enforcing these rules-the defendants in this case-has refused to provide any interpretations or definitions which would solve the dilemma. Indeed, despite repeated questioning at oral argument, counsel for defendants was unable to draw any line of demarcation between solicitation and advertising.

Id. at 888.

${ }^{124}$ For years economists struggled to distinguish "informative" from "persuasive" advertising, on the theory that only the former truly benefited consumers. Most economists now realize, however, that the distinction is mere "metaphysics," Johnson, The Economics of Advertising, in READINGS IN THE ECONOMICS OF INDUSTRIAL ORGANIZation 410, 413 (D. Needham ed. 1970), and that the controversy is simply "a red herring," E. Mishan, 21 Popular Economic Fallacies 115 (1970)). Every advertisement supplies some information, if only a reminder of the firm's existence and the product the firm sells. Moreover, even "persuasive" advertising can improve consumer welfare by promoting the rapid entry of superior products into the market, by enhancing competition and thereby lowering prices, by stimulating product innovation and by reducing search costs for consumers. See Leffler, Persuasion or Information?: The Economics of Prescription Drug Advertising, 24 J. L. \& EcoN. 45 (1981).

125 See Grady, Regulating Information: Advertising Overview, in The Federal Trade Commission Since 1970, at 222, 222 (K. Glarkson \& T. Muris eds. 1981). Professor Grady maintains that the "main economic justification for advertising is that 
tially benefits both buyers and sellers. Each is also potentially deceptive.

With a variety of promotional techniques available to sellers, how do they actually promote themselves? Contrary to Justice Powell's assertion, ${ }^{126}$ advertising is not the traditional form of seller promotion in the economy generally, nor is it the most important. Advertising was not widely used before the advent of television and radio. ${ }^{127}$ Only with the rise of mass media in this century has advertising assumed its current prominence. Even today, perhaps surprisingly, "what is nominally called advertising forms only a small part of the total resources intended to make buyers aware of goods and services." ${ }^{\text {"2s }}$ Advertising costs averaged $1.6 \%$ of sales revenues in 1975, whereas nonadvertising promotional expenses amounted to $7.3 \%$ of sales. ${ }^{129}$

The smaller role of advertising compared with other means of promotion in the economy as a whole also holds true for the professions, notably the legal profession. ${ }^{130}$ The most recent surveys indicate that some thirteen percent of lawyers have advertised since it has been permitted. ${ }^{311}$ It appears, however, that many more attract business via other means-illicit and licit. Among the illicit techniques, paid referrals from clients, fellow lawyers, and others represent, according to one observer, "the most important source of business" for beginning lawyers. ${ }^{132}$ Other commentators state that "lawyers have long known that

it reduces consumer search costs and makes consumer search more effective." Id. If it were not cheaper for sellers to provide the information in lieu of having consumers search for it, some sellers would cease to promote and lower their prices by more than the cost to consumers of getting the information. Nonadvertising sellers could then drive out of the market those sellers who continued to promote.

${ }^{128}$ See Bates v. State Bar of Arizona, 433 U.S. 350, 397 (1977) (Powell, J., dissenting) ("IA]dvertising is the most commonly used and useful means of providing information as to goods and other services ....".).

127 In 1929 , advertising costs accounted for only $\$ 2$ billion out of an estimated $\$ 14.4$ billion in aggregate selling costs. See Kaldor, The Economic Aspects of Advertising, 18 REv. ECON. STUD. 1, 25 (1950).

${ }_{128}$ Telser, How Much Does It Pay Whom to Advertise?, Am. Econ. Rev., May 1961, at 194, 194 (Papers and Proceedings).

129 See Weiss, Pascoe \& Martin, The Size of Selling Costs, 65 Rev. EcoN. \& Statistics 668 (1983).

130 Since more data on promotion are available for the legal profession than for other professions, this section concentrates on the legal profession. When available, data from other professions are cited. As will be seen, the data from other professions corroborate those for the legal profession. For a discussion of the relative unimportance of advertising as compared to direct selling (solicitation) in public accounting, see Dupuy, Practitioners Forum: The Direct Solicitation Issue, J. Accr., Oct. 1980, at 84. (1984).

131 See LawPoll, 69 A.B.A. J. 892 (1983); LawPoll, A.B.A. J., June 1984, at 48

132 M. Mayer, The Lawyers 60 (1966). The Supreme Court has not considered the use of referral fees, which the bar continues to ban. See Model Rules of Professional Conducr Rule 7.3 (1983). The bar has never adequately explored the 
client referrals are probably the most effective means of obtaining new work." "13s Jerome Carlin determined that forty-four percent of lawyers he surveyed in New York City pay clients for referring new clients. ${ }^{134}$ Although the practice is prohibited, lawyers speak matter-of-factly about it. ${ }^{135}$ Likewise, Carlin found that fifty-six percent of lawyers sur-

value of referral fees to both sellers and consumers. In the case of fees paid to other lawyers, referrals create the incentive for professionals who have less experience or expertise in a particular subject area to pass the client on to an experienced professional in return for a "finder's fee"-some portion of the fee ultimately paid. If referral fees are outlawed, the first lawyer contacted can profit only by doing the work herself, which may mean inferior service for the client. Referrals are merely a way of accomplishing between lawyers in different firms exactly what happens every day between lawyers in the same firm, where the lawyer who first attracted a client may refer the client to a colleague with a different specialty but still "get credit" for fees generated when firm income shares are later allocated. See McChesney, supra note 115, at 393 n.34. The bar's justification for banning referral payments between firms appears to rest on a belief that the size of the referral fee, rather than the superior competence of another lawyer, will influence the referring attorney. But only a lawyer who can do equivalent work at lower cost, or better work at the same cost, has any incentive to pay for referrals in the first place. If the second lawyer has even less experience in a particular area than the first, it will cost that lawyer more to perform the work. The second lawyer thus will not be able to offer a fee sufficient to bid the work away from the first.

In the case of referral fees paid to clients or other laymen, the bar's fears may seem to have more substance, but only superficially. Nonprofessionals will naturally refer to whichever attorney pays the highest fee, regardless of quality. But again, those who can do the work at lowest cost can offer the highest referral fees. Even if motivated solely by size of fee, lay referrors will nevertheless be led to refer to the most efficient provider of professional services.

1s3 Smock \& Heintz, supra note 117, at 1434 . Client and other third-party referrals are also the two most influential factors for executives' selection of a public accounting firm. See George \& Solomon, Professional Notes: Marketing Strategies for Improving Practice Development, J. AccT., Feb. 1980, at 79, 80 (Table 1) (1980).

134 J. Carlin, Lawyers' Ethics: A SuRvey of THE New York Gity Bar 58 (1966). The percentage figure reported in the text is extrapolated from data presented in Carlin's Table 38. See id. (The extrapolation is obtained in the following way. First, multiply the percentages in the table by the totals for each category of law firm, which is given in parentheses at the bottom of each column. Next, sum these numbers. Finally, divide this sum by the total number of lawyers responding.) Carlin's final sample included 881 lawyers practicing in the "central business core" of New York City. Of these, 801 responded to Carlin's questionnaire. See id. at 9. He cautions that

[t] ]he [study's] findings cannot necessarily be generalized to all metropolitan bars, and certainly not to bars in the smaller cities. Nevertheless, of lawyers in large metropolitan centers (over one-half million population) of the United States, approximately one-third are located in New York City. Furthermore, such data as there are from these other metropolitan bars are strikingly similar to our findings in New York City.

Id. (footnote omitted).

135 Carlin quotes a sole practitioner on the use of client payments: "If they send in business on a regular basis, I give a gratuity; if it's an occasional referral, I don't have to. I give gratuities in about 10 to 15 per cent of the cases." J. CARLIN, supra note 120, at 81. Another sole practitioner denied giving gratuities, but added, "I get most of my clients on referrals from other clients. So, when I wind up a case for a client, I invite the client for drinks or lunch-it leaves a good going-away impression." Id. 
veyed pay for referrals from other lawyers, with the payments involving a substantial cut of the fees. ${ }^{\mathbf{1 3 6}}$ Finally, Carlin found that some thirtyseven percent of lawyers who spend appreciable time at court mainly "wait around," apparently to solicit clients. ${ }^{137}$ All in all, despite sketchy data, one would conclude that lawyers apparently find illicit means of promotion more useful than advertising. ${ }^{138}$

Of course, many ways of attracting business are not considered unethical. For example, lawyers recognize that pro bono work, unpaid legal services supposedly contributed by a law firm for altruistic or charitable reasons, is also a form of solicitation that enhances a lawyer's reputation and increases contacts in the community. ${ }^{139}$ In one study, Philip Lochner found that lawyers take pro bono clients "in return,

${ }^{130} \mathrm{~J}$. CARLIN, supra note 134 , at 58 . The percentage figure reported in the text is extrapolated from Carlin's Table 38. See id. In his study of sole practitioners, Carlin noted that most of the more successful lawyers "rely heavily on referrals from other lawyers, several reporting that well over half their business is obtained in this manner. The referring lawyers are rewarded, usually willingly, with a third to a half of the fee." J. CARLIN, supra note 120 , at 82 .

${ }^{137} \mathrm{~J}$. Carlin, supra note 134, at 26. Carlin found that $37 \%$ of New York City lawyers surveyed who spend at least two hours per week at the courts pass most of that time "waiting around." The percentage figure reported in the text is extrapolated from Carlin's Table 13. See id. at 26. Describing the promotional value of "waiting around" the courthouse, Carlin quotes one criminal lawyer:

Every day ... I'm at the Court .... I never liked it . . . but I have no choice. People come into these neighborhood courts-they have no foresight-without a lawyer and needing one. They learn to expect one around ... . The bondsmen, sometimes they come in and ask us to take a case ....

J. CARLin, supra note 120, at 107-08. Carlin comments on the lawyer's need for "maintaining more or less regular sources of business, which means he has to give something to the bondsmen and precinct captains." Id. at 108.

${ }^{138} \AA$ recent survey of lawyer attitudes toward solicitation found that, of those expressing an opinion, lawyers agreed three to one that solicitation was more effective for obtaining clients than advertising. See Murdock \& Pattison, supra note 76, at 278 (Table 1).

139 A veteran solo practitioner, for example, recommends that

a young, rural, solo practitioner . . . take up public defending. He's got to get some business or he's gonna starve to death. The courts are begging for pauper lawyers. . . . If a young lawyer is proficient and gets acquainted around town, he'll begin to pick up probate work, damage suits and divorces. Other lawyers who have more than they can handle will give him some of the work they don't want.

Emmerman, City Lawyer/Country Lawyer: Solo Virtuosos, STUdenT LAw., April 1977 , at 14,59 . That pro bono work is at least partly motivated by promotional rather than altruistic interests may explain why, in a survey of lawyers' opinions of fellow lawyers, attorneys expressed no admiration for others who engaged in pro bono activities. According to a report of the survey, "Some of the criteria used by lawyers to rank their fellows were not anticipated by the surveyors. They expected lawyers would view pro bono work with deference, approving a commitment to social good. They were wrong." Cowger, What Kinds of Lawyers Do Lawyers Like Best?, 63 A.B.A. J. 787 (1977). 
most typically, for hoped-for future legal business."140 Joining civic clubs and organizations appears to be another popular way of making personal contacts, some of which eventually ripen into business. ${ }^{141}$ "Successful lawyers know that giving of their time freely to charitable and civic associations is an excellent way ... to help build their practice."142 Law firms, particularly larger ones, make increasing use of outside public relations firms and have even begun to employ lay marketing directors within the firm. ${ }^{143}$ In short, lawyers join country clubs and other social organizations and pursue various other schemes to land clients-all quite licitly, despite the seeming similarity between these schemes and prohibited solicitation. ${ }^{144}$

140 Lochner, The No Fee and Low Fee Legal Practice of Private Attorneys, 9 L. \& Soc'y REv. 431, 463 (1975). Lochner found that the pay-off from pro bono work might not come directly from the client served, but rather from a mutual acquaintance who referred the client. See id. at 463. Another indication of the link between pro bono and paid work is evident in England, where solicitors retained after giving free legal advice at "legal aid centers" have the burden of proving that they have not unethically "touted" themselves. See Attanasio, supra note 9, at 497.

141 One lawyer explains the rationale for membership in these groups as follows:

$[\mathrm{L}]$ awyers join a lot of organizations as a means of getting practice. . . . You just go around and impress people with your ability and personality. You join many organizations, professional, business, lodges, social clubs, country clubs, and politics, all designed to expand your circle of acquaintances on the theory that you are more likely to come in contact with people who need a lawyer.

J. CARlin, supra note 120, at 126-27.

${ }_{142}$ Davidson, Building a Law Practice, CASE \& Com., Nov.-Dec. 1980, at 15.

${ }_{143}$ See, e.g., LawPoll, 69 A.B.A. J. 892 (1983) (presenting data on law firms' use of public relations firms); Nelson, Big Firms Continue to Emphasize Marketing Tools, Survey Finds, Legal Times, April 23, 1984, at 1, col. 1 (survey showing "rapidly" increasing law firm interest in public relations firms); see also Heintz, Elements of Law Firm Competition, Nat'l L.J., Dec. 26, 1983, at 15, col. 2 (law firms "realigning their internal management approaches to support an organizational emphasis on marketing").

144 Despite the bar's almost monolithic stance against solicitation in theory, incidences of solicitation are far from rare. An attorney's chummy contacts with bankers, realtors, corporate executives and other people at a country club [have] been a traditional means of in-person contact to attract clients. "Most disconcerting to the notion that lawyers should not solicit business," wrote attorney Morley Walker in the Chicago-Kent Law Review, "is that [business] entertainment is a deductible fact of a taxpayer's life-for lawyers as well as for anyone else."

L. Andrews, Birth of a Salesman: Lawyer Advertising and Solicitation 67 (1980) (quoting Walker, Advertising by Lawyers: Some Pros and Cons, 55 CHI-KenT L. REv. 407, 418 (1979); see also Note, supra note 12, at $596 \mathrm{n} .63$ (citing cases and articles discussing ways lawyers legally can solicit); Note, Advertising, Solicitation and the Profession's Duty to Make Legal Counsel Available, 81 YALE L.J. 1181, 1204 n.142 (1972) (citing sources) [hereinafter cited as Note, Profession's Duty].

In accounting, interviews with representatives of businesses that hire accountants disclose that "informal solicitations do often occur through social or civic contacts with the partners of accounting firms." Carter, Edwards, Jackson \& Kirchhofer, Competi- 
There are fewer data available on lawyers' use of permissible promotion than on their use of illicit promotion. But from the evidence at hand, one would surmise that use of the various techniques is greater than the use of advertising for the average lawyer. For example, a national survey of almost 1,500 lawyers found that $6.2 \%$ of an average lawyer's billable time was spent doing pro bono work; almost one fifth of the respondents spent over ten percent of their billable hours in pro bono activity. ${ }^{145}$ As compared to the thirteen percent of lawyers who now have advertised, sixty-two percent of lawyers did pro bono work during nonbillable hours in the previous year (1973), at an average cost of $\$ 2,843$. $^{148}$ Even with adjustment for that portion of pro bono work that is truly altruistic, promotional pro bono work alone-not to mention club activity, public relations and all the other licit means of attracting business-appears to dwarf advertising in importance. ${ }^{\mathbf{1 4 7}}$

\section{B. Banning Promotional Techniques by Professionals}

\section{The Model}

Professional associations, including the bar, have traditionally permitted certain types of promotion by their members and prohibited others. The effects of banning some promotional devices while leaving others open to professionals can be analyzed by reference to a formal economic model. Two rather standard assumptions are made. First, for reasons discussed above, advertising and nonadvertising types of promotion are substitutes for one another in marketing goods and services, though not perfect substitutes. ${ }^{148}$ Second, advertising and other promotional inputs are viewed as subject to diminishing returns; $;^{149}$ that is, successive doses of each promotional input yield less and less additional return in increased sales. ${ }^{100}$ With these two assumptions, firms' use of

tion in Public Accounting: Issues and Impact, 1 GA. J. AccT. 74, 80 (1980).

${ }_{145}$ See Handler, Hollingsworth, Erlanger \& Ladinsky, The Public Interest Activities of Private Practice Lawyers, 61 A.B.A. J. 1388, 1389 (1975) [hereinafter cited as Handler].

${ }^{148}$ See id. at 1389.

147 Although other forms of promotion appear more useful than advertising, advertising is nevertheless valuable. Its value is attested to by figures showing that of the $13 \%$ of all lawyers who had advertised by $1984,82 \%$ intended to continue advertising. See King, What Works, What Doesn't, in Advertising, A.B.A. J., April 1985 at 54, 55 (1985).

148 See, e.g., R. Bilas, Microeconomic Theory 138-44 (2d ed. 1971) (discussing substitutability among inputs).

149 For a review of the large body of evidence showing diminishing returns to advertising, see J. Simon, Issues in THE Economics of AdVERTISING 1-22, 223-24 (1970).

${ }^{250}$ A managing partner of Hyatt Legal Services, the highest spending legal adver- 
promotional inputs can be modelled graphically, ${ }^{161}$ which will present a clearer picture of the effects of outlawing some inputs and allowing others.

Substitutability and diminishing returns are shown in Figure 1, which indicates the quantities of a good, such as professional services, that can be sold using two hypothetical inputs, $a$ and $b$. Imagine, for the sake of concreteness, that $a$ represents the quantity of advertising, and $b$ represents the quantity of pro bono work. A firm or individual professional can combine quantities $a_{1}$ and $b_{1}$ of each input to sell quantity $Q^{*}$ of the service promoted. Because $a$ and $b$ are substitutes, a firm can reduce the amount of $a$ used without reducing the quantity $\mathrm{Q}^{*}$ of the service sold, as long as more $b$ is added to replace the lost $a$. A lawyer or law firm, for instance, could reduce advertising but manage to bill the same number of hours by increasing his contacts through more pro bono work.

But because the returns to $b$ diminish, the firm must substitute successively greater units of $b$ as $a$ is progressively reduced in order to sell the same quantity $Q^{*}$ of the service in question. A reduction from $a_{1}$ to $a_{2}$ of the one input will require substitution from $b_{1}$ to $b_{2}$ of the other, if the same $Q^{*}$ is to be sold. But a second reduction in $a$ by the same amount, from $a_{2}$ to $a_{3}$, will require a larger increase in $b$, from $b_{2}$ to $b_{3}$, if $Q^{*}$ is still to be sold. Thus, diminishing marginal returns to promotional inputs implies that constant-output curves (or "isoquants") like $Q^{*}$ are convex to the origin (point $O$ in Figure 1). It is important to distinguish diminishing marginal returns to a single input from the effects of increasing both inputs simultaneously. An increase in both inputs allows the firm to increase the quantity of services sold. A firm can sell $Q^{* *}$ rather than $Q^{*}$ of its services by increasing both promotional inputs, for example to $a_{4}$ and $b_{4}$ from $a_{1}$ and $b_{1}$. Isoquants further from the origin therefore represent higher quantities of services sold: $Q^{* * *}$ is greater than $Q^{* *}$, which is greater than $Q^{*}$.

Naturally, sellers will want to combine inputs $a$ and $b$ in such a way as to minimize the total cost of promoting a given level of services. If sellers can purchase the promotional inputs $a$ and $b$ at constant prices $P_{a}$ and $P_{b}$ respectively, the total costs of selling for different quantities of services are represented by a series of isocost or "budget" lines, each with a constant slope of $-\mathrm{P}_{\mathrm{a}} / \mathrm{P}_{\mathrm{b}}$. The budget line simply

tiser in the country, expresses succinctly the phenomenon of diminishing marginal returns when he notes that "[o]ver time, the percentage of persons who come to us [because of advertising] decreases." "Middleton, supra note 110, at 24, col. 3.

181 See R. Bilas, supra note 148; C. Ferguson, The Neoclassical Theory of Production and Distribution (1969). 
shows the different combinations of the promotional inputs that can be purchased with a constant promotional budget. In Figure 1, for example, the same budget can be used to purchase OR of input $b$ and no $a$, OS of input $a$ and no $b$, or any combination of $a$ and $b$ that lies in between on the budget line RS. Budget lines further from the origin in Figure 1 mean greater total costs of promotion. For instance, the line TU represents greater total promotion costs than the line RS. This relationship can be seen from the fact that with TU a professional seller can purchase more $a$ with no $b$ (OU is greater than OS) or more $b$ with no $a$ (OT is greater than OR) than with RS.

\section{Promotional}

input $b$

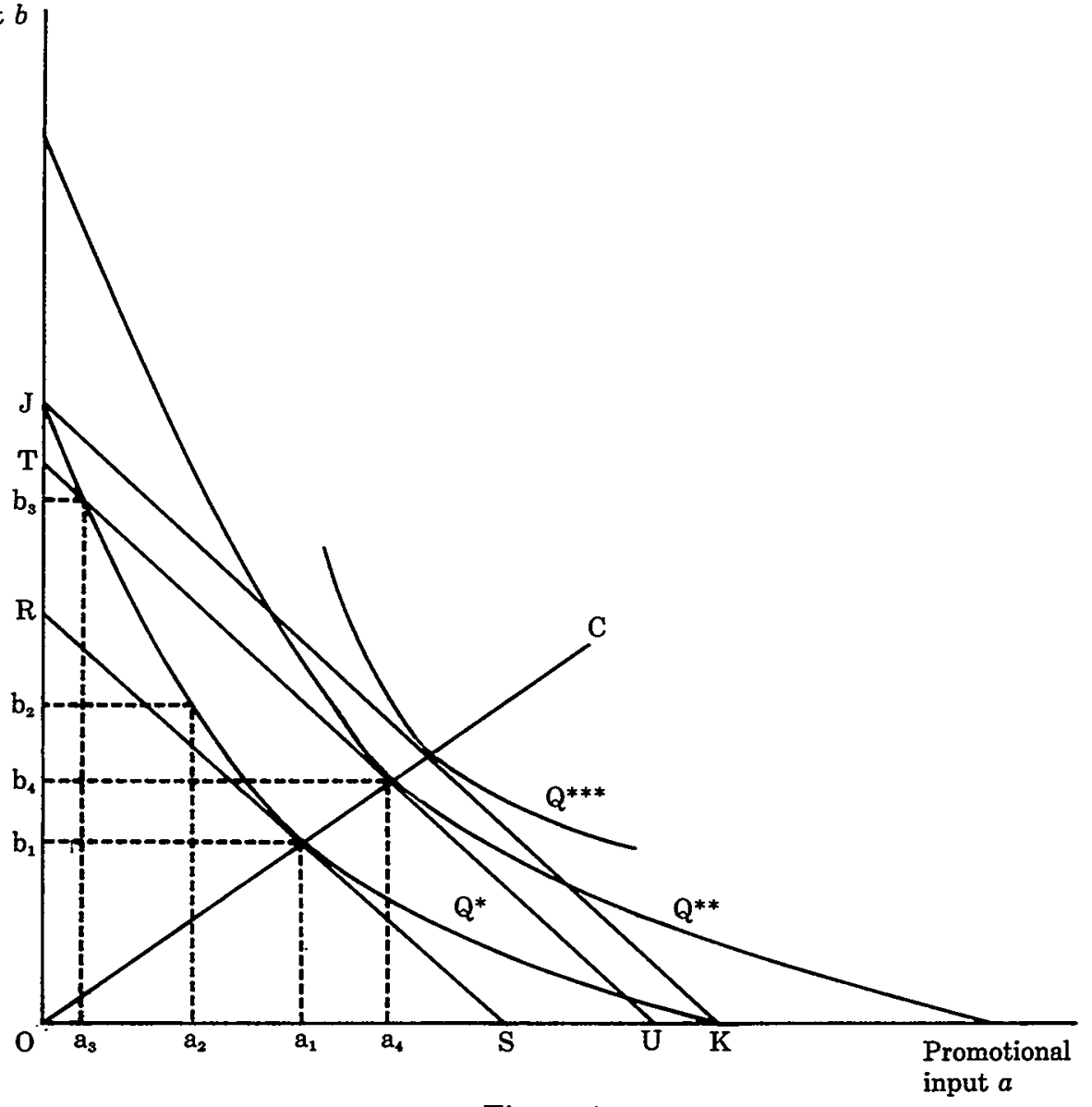

Figure 1

The model in Figure 1 is helpful for illustrating the appropriate combination of promotional inputs for the seller of professional services. The cost-minimizing level of $a$ and $b$ for promoting any given level of 
service is achieved where the budget line is tangent to the isoquant curve. The least-cost input combination for $Q^{*}$, for example, is $a_{1}$ and $b_{1}$, the point of tangency with budget line RS. That this point is the least-cost combination of promotional inputs can be seen by comparing the budget line for any other combination needed to sell $Q^{*}$. If $a_{3}$ and $b_{3}$ are used, for example, the higher budget defined by TU is needed to sell $Q^{*}$. Indeed, the higher cost defined by TU would actually enable a firm or individual professional to sell a greater quantity of services, $Q^{* *}$, if the two promotional input levels were changed to $a_{4}$ and $b_{4}$.

Thus, $a_{3}$ and $b_{3}$ are inefficient combinations of promotional inputs, because the same quantity of services, $Q^{*}$, could be sold at lower cost if the same budget were allocated to the $a_{1}, b_{1}$ combination instead. The line OC shows the series of efficient input combinations as output sold expands, and so defines the firm's promotional "expansion path." Only by combining promotional inputs at points along the expansion path (OC) will a firm be selling at lowest cost.

Whether the firm actually promotes efficiently therefore depends on its ability to choose the optimal combination of promotional inputs--those defined by the expansion path OG-for the level of services sold. In the professions, however, firms are not free to use their preferred levels of all inputs. Some inputs, such as solicitation, trade names and, until recently, advertising, have traditionally been banned. To illustrate the effect of input constraints, suppose that firms are prohibited from using input $a$ in Figure 1. Instead of combining inputs efficiently by using the combinations of $a$ and $b$ along the expansion path OG, the firm must choose the point on the vertical axis representing enough $b$ to sell a given level of services when no $a$ can be used. If a firm wants to sell output level $Q^{*}$, the inability to combine $a$ with $b$ efficiently means that the firm must use OJ of $b$ alone. Therefore, the firm must incur the higher total promotion cost represented by JK to achieve this output level, rather than the lower cost depicted by RS that the firm would spend if it could use the prohibited input, $a$.

The foregoing economic model can help analyze some effects of the Supreme Court's commercial speech doctrine. Input $a$ can represent any banned input useful to professionals for conveying desired information to potential clients. The model demonstrates that, putting deception aside, banning any promotional input has the same effect of raising the cost of a given level of promotion. For banned input $a$ in Figure 1, replace advertising with solicitation or use of trade names. Analytically, the result is the same. The ban will prevent the professional from attaining the lowest-cost mix of inputs for selling a given level of services. The professional therefore must substitute more of the permitted pro- 
motional device, resulting in a costlier input choice. This point has begun to dawn on consumer specialists, ${ }^{152}$ antitrust enforcers, ${ }^{153}$ and economists. ${ }^{154}$ One observes precisely the same substitution effect outside the professions when one form of promotion is banned. ${ }^{165}$ When some promotional devices are banned, the substitute forms of promotion may be less desirable than those outlawed. ${ }^{156}$ Yet, in allowing the bans on solicitation and trade names to stand, the Supreme Court has neither asked what inputs professionals will substitute for those banned, nor examined what effects such substitution will have.

Several effects of banning promotional inputs merit attention. First, as a plethora of empirical studies of professions convincingly shows, the price of services rises significantly. ${ }^{157}$ In the theoretical

152 See Murdock \& Pattison, supra note 76, at 267 ("Removing the ban on solicitation [would offer] many of the same advantages to consumers as the removal of the ban on advertising.").

153 Federal antitrust officials now accept that promotional restrictions in the professions have the same kinds of effects, regardless of whether the restrictions apply to advertising, solicitation or other types of promotion. Consequently, as previously discussed, see supra note 16, the FTC has successfully challenged as anticompetitive medical associations' restrictions not just on physicians' advertising but also on their solicitation and other promotional practices. In addition, the Antitrust Division of the Department of Justice has entered into a consent agreement with the Association of Engineering Geologists, ending that group's prohibition of both advertising and solicitation. See Professional Association Agrees to Cancel Restraints on Advertising, 46 ANTItrust \& Trade Reg. ReP. (BNA) No. 1166, at 1015-16 (May 24, 1984). The Antitrust Division also is currently challenging as anticompetitive advertising and solicitation restrictions maintained by the Louisiana State Board of Certified Public Accountants. See United States v. State Bd. of Certified Pub. Accountants, No. 83-1947, at 6-7 (E.D. La. filed Apr. 15, 1983). Most recently, the Antitrust Division has warned state supreme courts that it considers the bar's rule banning solicitation, see MODEL Rules of Professional Conduct Rule 7.3 (1983), to be anticompetitive and overbroad. See McGrath letter, supra note 15; Taylor, ABA Rules on Fees and Clients Receive Antitrust Warning, Wall St. J., Sept. 25, 1984, at 16, col. 3.

104 One commentator has observed that "expenditures on advertising are only one among several alternative methods a seller may use. ... [D]irect regulation of the absolute or relative amount of advertising is unwise. . . . Substitution among kinds of promotional expenditures may be possible which would only shift the problem, not mitigate it." Mann, Advertising, Concentration, and Profitability: The State of Knowledge and Directions for Public Policy, in Industrial Concentration: The New Learning 137, 153-54 (H. Goldschmid, H. Mann, \& J. Weston eds. 1974).

${ }^{155}$ For example, since the 1971 ban on televised cigarette commercials, tobacco companies have responded by sponsoring "music festivals, car races, tennis tournaments and the like," all for their publicity value. Guyon, To Tout Merit, Phillip Morris Creates News, Wall St. J., Aug. 21, 1981, at 21, col. 3.

${ }^{156}$ Doyle agrees that "if advertising alone were restricted, it seems likely that other means, perhaps less desirable would be found by firms for reducing market uncertainties." P. Doyle, A Stochastic Theory of Advertising: Decision-Making and the Theory of the Firm 227 (1971) (unpublished Ph.D. dissertation, Carnegie-Mellon University).

157 See, e.g., Cleveland Regional Office, Bureau of Economics, Fed. Trade Comm'n, Improving Consumer Access to Legal Services: The Gase FOR REMOVING RESTRICTIONS ON TRUTHFUL ADVERTISING 126 (1984) (concluding 
framework of Figure 1, if a professional or firm includes the average cost of promotion in each unit of the $Q^{*}$ services sold, prices rise by $\left[(\mathrm{OJ}-\mathrm{OR}) \mathrm{P}_{\mathrm{b}} / \mathrm{Q}^{*}\right]$ when input $a$ is banned. It is perhaps not selfevident that allowing promotion actually could lower prices. Promotion is a costly process and so must be covered by the prices consumers pay. As a result, before professional advertising became commonplace, many believed that allowing advertising or other promotion would only raise prices. ${ }^{168}$ But this belief failed to reckon with professionals' desire and ability to substitute other, less efficient (that is, more costly) promotional techniques for the inputs banned. When a form of promotion is banned, professionals do not stop promoting. Instead of soliciting or paying referral fees, lawyers may (and do) join country clubs and run for political office to promote themselves and their practices. ${ }^{168}$ Physicians also have long promoted themselves by more costly means when standard promotional channels were closed. ${ }^{160}$ The traditional prohibi-

that various restraints on advertising all have the effect of raising prices of legal services) [hereinafter cited as FTG Staff Report: Access to Legal SERvices]; FTC STAFF REPORT: ADVERTISING Restrictions IN OPTOMETRY, supra note 40, at 2526 (concluding that advertising by optometrists results in lower prices); Benham, The Effect of Advertising on the Price of Eyeglasses, 15 J.L. \& EcoN. 337, 344 (1972) (finding that advertising restrictions increase eyeglass prices by $25 \%$ to more than 100\%); Cady, An Estimate of the Price Effects of Restrictions on Drug Price Advertising, 14 ECON. INQUIRY 493, 501-02 (1976) (finding that restraints on prescription drug price advertising raise prices an average of 2.9\%); Steiner, Does Advertising Lower Consumer Prices?, J. MaRketing, Oct. 1973, at 19, 23-26 (presenting evidence from the toy industry that advertising lowers prices).

${ }^{158}$ See, e.g., Cady, supra note 157, at 494 ("[I]t is often asserted that price advertising increases drug prices because the cost of advertising is passed along to consumers."). The following statement typifies this widely held view:

I am not confident that additional revenues [sufficient to cover the cost of advertising] ... are available in the marketplace, at least in the near term.

In the absence of a significant increase in revenue the [money] spent on advertising . . . can come from only two sources: either the costs are passed on to our clients in higher fees or they are absorbed by partners in the form of reduced compensation.

Auerbach, Competition in Public Accounting: Issues and Impact, 1 GA. J. Accr. 1, 11 (1980). Despite this view's popularity, the Supreme Court has correctly rejected the claim that advertising results in higher prices. See Bates v. State Bar of Arizona, 433 U.S. 350, 377-78 (1977); Virginia State Bd. of Pharmacy v. Virginia Citizens Consumer Council, 425 U.S. 748, 768 (1976).

169 See De Alessi, Discussion, in Advertising and Free Speech 98 (A. Hyman \& M. Johnson eds. 1977) ("[I]t has been remarked that attorneys are discouraged by the legal cartel from advertising their wares. Higher-cost substitutes, however, are available. For example, lawyers can and do acquire and exercise the right to advertise simply by becoming candidates for public office.").

${ }_{100}$ For example, some doctors have hired public relations firms. See Young, Physician Advertising-Legal and Ethical Considerations, TEx. MED., March 1983, at $79,79 \&$ n.1 (introduction). Others have written books and have appeared on television talk shows to promote the books. See Hull, If the Doc's on TV, Maybe It's Because He 
tion on solicitation in their profession "has made accountants masters of the art of indirect solicitation."161 Once the possibility of substituting inputs at higher cost is recognized, it is easier to see why banning promotional inputs would raise, not lower, promotion costs and thus consumer prices.

A second consequence of costly substitution and the resulting higher prices is that fewer consumers purchase professional services. Critics of advertising by lawyers have often

failed to recognize that legal services are delivered in a market .... As in other aspects of economic life, consumers assess the costs and benefits of purchasing a legal service in light of the specific problems before them, their resources, and their desires for goods and services of other types. Consumers will purchase legal assistance when they believe that the transaction produces greater benefits than can be obtained by purchasing other goods or services at that price. ${ }^{\mathbf{1 6 2}}$

Takes the $P R R x$, Wall St. J., Aug. 23, 1983, at 1, col. 2. For a report of how one dentist induced his wife to interrupt her career as a night-club singer, so she could entertain in his office in order to increase business, see Bean, Live, From the Dentist's Office, He-e-e-e-e-e-r-r-r-r-e's His Wife! Wall St. J., Feb. 7, 1985, at 33, col. 1.

161 Bernstein, Competition Comes to Accounting, ForTune, July 17, 1978, at 89. One writer observes that, with solicitation banned,

firms must content themselves with a less frontal approach, so they sponsor seminars on a variety of financial topics for the business community, distribute booklets and brochures on accounting and tax issues and try to land speaking engagements at meetings of various influential business groups.

Most important, accounting firms press their people to gain entry to the playground of corporate America by joining the "right" civic groups, country clubs and religious organizations.

Rankin, How C.P.A.'s Sell Themselves, N.Y. Times, Sept. 25, 1977, at F1, col. 1, F13, col. 1. See also Auerbach, supra note 158 at 1 (discussing competition for clients through "indirect channels"); Bernstein, supra, at 89 (providing a thorough description of the various ways accounting firms, particularly the largest, Peat, Marwick, Mitchell \& Co., attract business without running afoul of local bans on solicitation); Mette, Competition in Public Accounting: Issues and Impact, 1 GA. J. AccT. 18, 22 (1980) (describing the "competitive fever" among CPA's, as indicated by their hiring public relations advisers in an attempt to increase recognition among local businesses).

${ }^{162}$ Hazard, Pearce \& Stempel, supra note 16, at $1091-92$ (footnotes omitted). If the promotional ban were lifted, then

since the price of professional services would fall, some people-the very poor-would be able to purchase services that were previously out of their reach. Instead of relying on neighbors, friends, pharmacists, and magicians for medical advice during an illness, the poor could consult physicians. The average quality of medical advice consumed would increase even if the average quality of medical advice given by physicians did not change.

C. Baird, Int'l Inst. Econ. Resources, Advertising by Professionals, 23 (1977). 
When the price of legal services falls, consumers purchase more of these services. In particular, "middle and low income consumers who currently do not purchase necessary legal services will be able to purchase such services." 163 As noted earlier, the Supreme Court recognizes that lower prices will increase the quantity of legal services purchased, but has vacillated on the normative implications of increased use of such services. According to the Court, greater resort to the legal system as a result of advertising, by increasing consumers' reliance on the legal system, vindicates legitimate rights, but increased use of the system due to solicitation serves only to "stir up" litigation. ${ }^{164}$

Third, because information is more costly when some inputs are banned, less information is actually provided; therefore, consumers who do purchase legal services make worse-informed decisions. "[P]rohibitions on certain forms of speech . . . [are] costly to consumers, who may not receive as much truthful, nondeceptive commercial information as they would absent the restraints."165 Of course, consumers may substitute their own search for some of the information professionals cannot provide. But such additional search would be more expensive than if the ban were lifted and professionals could use any promotional technique. ${ }^{186}$ Thus, as Professor Grady notes,

[a]side from the direct benefit of the time and other resources that consumers save, consumers receive two other benefits from advertising. First, when search costs are reduced, consumers are more likely to find the good rather than the bad buys; second, when sellers know that consumers are more likely to find the good buys, they will be less disposed and less able to offer bad buys. ${ }^{167}$

\section{Restrictions vs. Bans}

In addition to illustrating the price and information effects of promotional bans, the economic model facilitates appraisal of the distinction drawn by the Court between outright bans and less restrictive regulation of promotion. As Figure 1 shows, the more a professional would have used promotional input $a$ absent the restriction, the more a restriction on $a$ will increase costs. If a professional may use a6 of pro-

163 Hazard, Pearce \& Stempel, supra note 16, at 1091.

164 See Bates v. State Bar of Arizona, 433 U.S. 350, 376 (1977); Ohralik v. Ohio State Bar, 436 U.S. 447, 461 (1978); supra text accompanying notes 84-85.

188 Reich, supra note 64, at 794.

168 See supra note 125 and accompanying text.

I67 Grady, supra note 125 , at 222. 
motional input $a$ rather than none of it, the cost necessary to sell $Q^{*}$ of services increases by only $\left[(O T-O R) P_{b}\right.$ ] rather than $\left[(O J-O R) P_{b}\right.$ ]. Thus, although a restriction increases costs in the same manner as a ban, the extent of the restriction's adverse effect on prices and information is less. ${ }^{168}$ The price increase caused by the restriction, [(OT-OR) $\left.\mathrm{P}_{\mathrm{b}} / \mathrm{Q}^{*}\right]$, is less than the price increase caused by the ban, $[(\mathrm{OJ}-\mathrm{OR})$ $\left.P_{b} / Q^{*}\right]$. The availability of services and useful information are both functions of price changes, as discussed above. Therefore, losses in service availability and in information are reduced if promotion is restricted but not altogether prohibited.

Empirical evidence corroborates this theoretical analysis that as the stringency of the promotional restriction increases, the extent of the adverse effects rises concomitantly. For example, in a highly sophisticated statistical study, the staff of the Federal Trade Commission examined the separate effects of a series of promotional restrictions in the legal profession. ${ }^{\mathbf{1 6 9}}$ Separate prohibitions on fee advertising, radio advertising, television advertising, and the use of handbills were all found to raise the prices consumers pay for lawyers. The FTC study concluded that "there appears to be a continuous relationship between prices and regulations, with the lowest prices associated with the fewest restrictions on attorney marketing practices." ${ }^{170}$ Similarly, empirical researchers have found positive correlations between the severity of advertising restrictions and price increases in other professions, such as pharmacy and optometry. ${ }^{171}$

The regulation/prohibition distinction illustrates a broader point of particular relevance for the Court's attempt to differentiate advertising from nonadvertising means of promotion. As the statistics discussed above indicate, lawyers' use of solicitation, payments to clients, and referral fees to other lawyers all outweigh their use of advertising. ${ }^{172}$ Thus, the adverse price, availability and information effects of banning

${ }^{188}$ Whether it nevertheless makes sense to impose promotional regulations despite their adverse effects of higher prices, reduced service, and limited information, depends on the amount and cost of deception avoided. See infra notes 223-77 and accompanying text. 126.

169 See FTC Staff Report: Access to Legal Services, supra note 157, at 170 Id.

171 Both Benham and Cady found that increasing severity of promotional restrictions was positively related to price. Cady, for example, found that explicit prohibitions of advertising had a greater effect on drug prices than the outlawing of "promotional schemes," like senior-citizen discounts, though both sorts of restrictions increased prices. See Cady, supra note 157 , at 504 . Benham similarly found that banning only price advertising had a less significant effect in raising prices than did banning all advertising. See Benham, supra note 157, at 343.

172 See supra text accompanying notes 130-47. 
these nonadvertising promotional techniques would be considerably greater than those of an advertising ban, all else being equal. There is an unfortunate irony here. The Court now protects advertising in the name of consumers but refuses to recognize that bans on other promotional inputs may have an even greater adverse impact on consumers than did the advertising prohibition.

\section{Competitive Implications}

The simple model presented in Figure 1 also provides a useful beginning for analyzing the competitive effects of promotional restrictions imposed on professionals. A ban on a type of promotion deprives professionals of one means of competing in the marketplace-vying to supply better information about themselves and their services. Inability to provide information cheaply also indirectly affects other ways firms compete. For example, the incentive to cut prices in order to compete more effectively diminishes when professionals cannot quickly and inexpensively inform the public of the price reductions. ${ }^{173}$ As a result, promotional bans self-imposed by professional organizations have been held illegal under the antitrust statutes. ${ }^{174}$

Nevertheless, the model in its simplest form fails to capture all the anticompetitive effects of banning certain promotional inputs while allowing others. Implicit in Figure 1 is the assumption that all professional firms are homogeneous, that is, they have the same set of isoquant curves and so combine promotional inputs $a$ and $b$ in exactly the same ratios to produce services. Because firms differ in age, size, location and other ways, however, it is more likely that firms would combine inputs in different ratios. If unconstrained use of both inputs were allowed, for example, some law firms would doubtless use more advertising while others would use more solicitation.

This more complex situation is captured in Figure 2.

173 See Scheidell, The Price Reducing Potential of Advertising, 39 S. EcoN. J. 535, 541-42 (1973).

174 See United States v. Gasoline Retailers Ass'n, 285 F.2d 688 (7th Cir. 1961) (holding that an agreement among competitors to limit advertising violates $\S 1$ of the Sherman Act); In re American Medical Ass'n, 94 F.T.C. 701 (1979), modified, 638 F.2d 443 (2d Cir. 1980) (holding that bans on physician advertising and solicitation imposed by medical associations violate $\S 5$ of Federal Trade Commission Act), affd mem., 455 U.S. 676 (1982). 


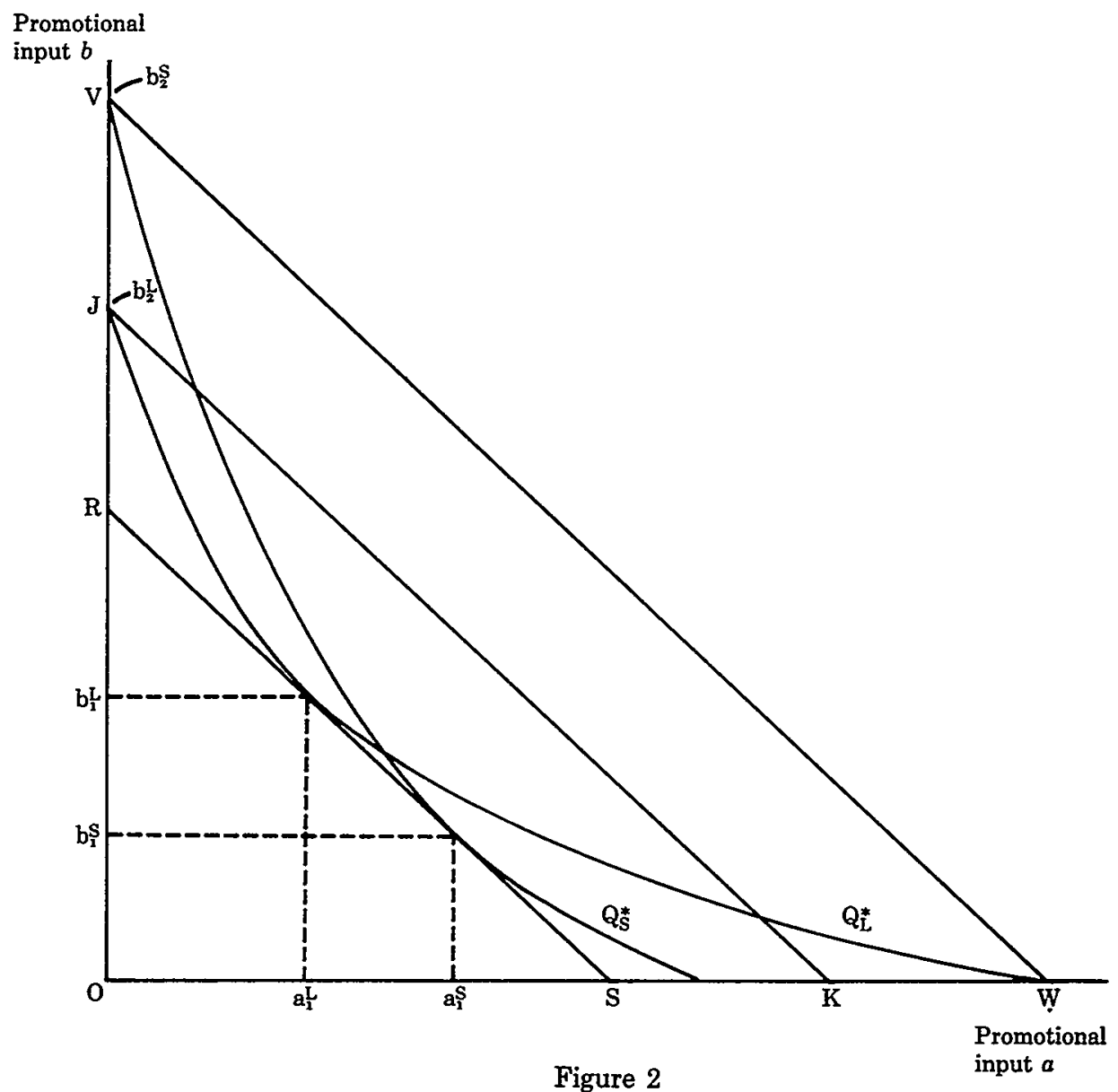

Suppose that the legal profession were composed of only two groups of firms: "leading" firms and "secondary" firms. Leading firms have respected reputations in the profession because these firms have provided quality services for many years. Secondary firms are relative newcomers to the profession, though they provide equal quality services. Suppose further that, absent promotional restrictions, leading and secondary firms would efficiently use the promotional inputs $a$ and $b$ in different combinations to produce the same quantity $Q^{*}$ of services. The isoquant curves showing the various mixes of promotional inputs are labeled $Q_{\mathrm{L}}^{*}$ for the representative leading firm and $Q_{\mathrm{s}}^{*}$ for the representative secondary firm. If it were free to use inputs as efficiency dictated, the secondary firm would use less $b\left(\mathrm{~b}_{1}^{\mathrm{s}}\right)$ and more $a\left(\mathrm{a}_{1}^{\mathrm{s}}\right)$ to produce quantity $\mathrm{Q}^{*}$ than leading firms, which would use more $b\left(b_{1}^{L}\right)$ and less 
$a\left(a_{1}^{L}\right)$. Although each type of firm would choose a different combination of inputs, there is no difference in the total cost of promotion between the two types of firms. The promotion budget needed to produce $\mathrm{Q}^{*}$ is depicted by $\mathrm{RS}$ for both firms. Thus, there is no difference in overall promotional efficiency between the two firms, because each spends the same amount on promotion to sell the same level of services.

If a ban on $a$ is imposed, however, the effects differ for the two types of firm. Neither firm may mix inputs; both must choose a level of $b$, represented by a point on the $b$ axis, that is off their expansion paths of least-cost input combinations. But because secondary firms must cut back more than leading firms in their use of $a$ (from $\mathrm{a}_{1}^{\mathrm{s}}$ to $\mathrm{O}$, rather than from $a_{1}^{L}$ to $O$ ), secondary firms must substitute more of $b$ to maintain the same level of services (from $b_{1}^{s}$ to $b_{2}^{s}$ rather than from $b_{1}^{L}$ to $\left.b_{2}^{L}\right)$. Both firms' costs of promotion rise, but costs for leading firms (OJ $\times \mathrm{P}_{\mathrm{b}}$ ) are now less than those for secondary firms (OV $\times \mathrm{P}_{\mathrm{b}}$ ).

The more complex model of Figure 2 illustrates how the adverse price, availability and information effects of banning a promotional input can have important competitive implications. Before the imposition of a ban, firms of different sorts may be equally efficient though they combine inputs in different ratios. But firms that can produce efficiently only by using more of one input are disadvantaged competitively when that input is banned. To substitute for the input prohibited they must incur higher promotional costs, and then must charge higher prices than their competitors to cover the increased costs. Correspondingly, firms that use less of the banned input enjoy a competitive advantage. ${ }^{175}$ These competitive distortions affect consumers as well. It is,

175 This discussion of promotional input restrictions treats the costs of promoting professional services as independent of the costs of producing them. However, restricting the use of promotional inputs may also affect a firm's production costs. Production costs tend to fall as the level of planned production rises, due to what economists term "economies of scale." See, e.g., Alchian, Costs and Outputs, in The Allocation of ECONOMIC REsources 23, 23-24 (M. Abramowitz ed. 1959). In a law office, as volume rises, the use of more printed forms and paralegals may become cheaper. See Muris \& McChesney, supra note 41, at 183-88 (discussing these and other examples of how volume production can lower average production costs in law firms). Because restrictions on promotion increase the average total costs to a professional firm, firms would find the volume of services sold would decrease, which in turn would raise the costs of production.

For example, Benham's study of advertising bans in the eyeglass industry found that the promotional restrictions increased eyeglass prices because they prevented firms from attaining scale economies. See Benham, supra note 157, at 344; accord Brozen, Is Advertising a Barrier to Entry?, in AdVERTISING AND SocIETY 79, 99-101 (Y. Brozen ed. 1974) (showing how the ability to promote lowers the cost of production). For data on how advertising permitted one legal clinic to increase its volume of services produced, see Muris \& McChesney, supra note 41, at 194-95. The end of advertising bans in the medical profession in 1982 has apparently also had the effect of encourag- 
after all, the clients of the disadvantaged firms who disproportionately pay the higher prices, face the reduced availability of legal services and confront the more limited information about the services they purchase.

How applicable to the legal services market is the situation portrayed in Figure 2? In fact, the data show, it captures an important phenomenon overlooked not only by the Supreme Court but also by most commentators. Law firms differ substantially in their choice of promotional techniques. The "leading" and "secondary" firm labels used in Figure 2 should be read as "large" and "small" law firms. It is smaller law firms that systematically use more of the promotional inputs traditionally banned by state bars-advertising, solicitation, and referral fees. This fact is shown in Tables 1,2 , and 3.

Table 1 reveals that as of 1981, lawyers in firms of less than three lawyers are four times more likely to have advertised than those in firms of 11 lawyers or more. ${ }^{176}$

ing high-volume clinic operations. The number of medical clinics jumped from 400 in 1982 to 950 in 1983. See Sorenson, Hospitals and Doctors Compete for Patients, with Rising Bitterness, Wall St. J., July 19, 1983, at 1, col. 2.

In order to assess the full effect of a promotional restriction on different firms, one must keep in mind that the production-cost effects of a promotional restriction would not be uniform across all firms. Firms that must cut back more in their use of the restricted promotional input not only must increase other means of promotion to compensate but also suffer greater efficiency losses in production. Thus, the total impact of a ban on a particular promotional input is exacerbated when one analyzes differences in production-cost effects in addition to direct promotion-cost changes.

${ }^{178}$ One can test the statistical significance of the differences in lawyers' use of different promotional techniques. "Statistical significance" is a term of art, indicating the probability that differences in lawyers' use of promotional inputs by firm size as extreme as those observed could have occurred by chance rather than because of systematic differences in their demands for such inputs. Statistical significance is measured here by a chi-square one-sample test. For a description of this statistical test, see $\mathrm{E}$. Mansfield, Statistics for Business and Economics 328-31 (2d ed. 1983). Chisquare tests of the differences in lawyers' use of advertising in 1981 show that one can reject the hypothesis that lawyers from all firm sizes have equal demands for advertising, at a significance level of .01 . Thus, there is a probability of less than one in a hundred that lawyers in firms of different sizes do not differ systematically in their demands for advertising. [Chi-square tests on file with the University of Pennsylvania Law Review]. 
TABLE 1

INCIDENCE OF LAWYER ADVERTISING

$\underline{1981}$

16

11

4 $\underline{1979}$

9

8

4

As the percentages show, the gap has increased since 1979. More recent figures show that the difference between larger and smaller firms has widened even further since the last comprehensive data were reported in 1981. By 1983, only five percent of law firms with ten or more lawyers had advertised, while twenty-three percent of firms with three or fewer had. ${ }^{17 z}$ Consequently, Justice Powell was quite incorrect in his prediction that larger firms would use their greater resources to disadvantage smaller firms by outspending them. ${ }^{178}$ On the contrary, advertising has proved considerably more useful to smaller firms.

The same distinction apparently holds true for nonadvertising promotional techniques. Table 2 presents data gathered by Carlin on lawyers' indirect and direct solicitation of business while "waiting around" for clients at courts. ${ }^{178}$

177 LawPoll, 69 A.B.A. J. 892 (1983).

178 See Bates v. State Bar of Arizona, 433 U.S. 350, 403-04 (1977) (Powell, J., dissenting).

170 See J. Garlin, supra note 134, at 26. 


\section{TABLE 2}

\section{Lawyers Spending at Least Two Hours Per Week at Courts Who "Wait ARound"}

Size of Firm

Lawyers Who Report Time

Spent at Courts is Mainly

"Waiting Around" (\%)

Sole Practitioner

Small Firm

Medium Firm

Source: J. Carlin, Lawyers' Ethics: A Survey of the New York Gity BaR 26 (1966) (Table 13). Small firms are those with two to four lawyers; medium firms, five to fourteen lawyers; and large firms, fifteen lawyers or more. See id. at 19 (Table 7).

As Table 2 shows, the percentage of those surveyed who report themselves "waiting around" when they are at the courthouse rises as firm size decreases. ${ }^{180}$ Carlin also investigated the extent of lawyers' violation of the ethical provisions concerning referral payments to other lawyers and to clients (the latter of which he termed "client kickbacks"). As shown in Table 3, the extent of the ethical violations are again highly correlated with firm size, with smaller-firm lawyers and sole practitioners making the most referral payments. ${ }^{181}$

180 Chi-square testing of Carlin's data permits one to reject at a significance level of .01 the hypothesis that lawyers' propensity to spend nontrial time waiting at the courts is unrelated to firm size. Therefore, the chance is less than one in a hundred that the differences reported in Table 2 appeared by chance. [Chi-square test on file with the University of Pennsylvania Law Review].

181 Chi-square tests indicate that differences in lawyers' use of lawyer and client referral payments are statistically significant at below the .001 and just above the .05 levels, respectively. The chances that the differences reported in Table 3 were observed by chance are thus one in a thousand and one in twenty. [Chi-square tests on file with the University of Pennsylvania Law Review]. 


\section{TABLE 3}

LAWYers RePorting Unethical Activity Occurring in Their Practices

$\begin{array}{ccc}\text { Size of Firm } & \text { Lawyers Reporting } & \text { Lawyers Reporting } \\ \text { Client Kickbacks (\%) } & \text { Referral Payments (\%) }\end{array}$

Small Firms

Medium Firms

Large Firms
56

23

12
60

53

37

Source: J. Carlin, Lawyers' Ethics: A Survey of the New York City Bar 58 (1966) (Table 38).

Firm size reflects only one important difference in lawyers' use of and attitude toward various promotional devices. Younger lawyers and lower-income lawyers tend to favor more the forms of promotion traditionally banned by the bar. Table 4 presents data showing that younger, lower-income lawyers are far more likely to have advertised than older, higher-income lawyers.

TABLE 4

INCIDENCE OF LAWYER ADVERTISING

Age and Income

Lawyers Who Have

Advertised (\%)

Age

21 to 34

35 to 44

45 to 54

55 and older

Income

$\$ 25,00$ and less

$\$ 25,001$ to $\$ 35,000$

$\$ 35,001$ to $\$ 50,000$

$\$ 50,001$ and more 
Table 5 likewise indicates that the younger lawyer is and the lower the lawyer's income, the more favorable the lawyer is toward solicitation.

TABLE 5

LAWYERS FAVORING SOLICITATION

$\begin{array}{cc}\text { Age and Income } & \text { Lawyers Who Favor } \\ \text { Solicitation (\%) }\end{array}$

Age

21 to 34

35 to 44

45 to 54

55 and older $\quad 15$

Income

$\$ 25,00$ and less 41

$\$ 25,001$ to $\$ 35,000$

$\$ 35,001$ to $\$ 50,000$

$\$ 50,001$ and more 33

Source: LawPoll, 67 A.B.A. J. 1618, 1619 (1981).

A more recent survey of lawyers corroborates the differences shown in Table 5. ${ }^{182}$ Moreover, the findings reported in Tables 4 and 5 for legal services parallel those for other professions and industries. ${ }^{183}$

These results should hardly be surprising. One important source of consumer information about a professional's quality is the reputation the professional has built up through prior services to other clients. ${ }^{184}$ Newer attorneys have had less time and fewer opportunities to build up reputations, although the newcomers may be of a quality equivalent or even superior to that of more established competitors. For newcomers,

182 See Murdock \& Pattison, supra note 76, at 280-81 ("Lawyers with more years of practice disagreed more strongly than their less experienced colleagues with solicitation in person, by phone, and by mail. . . . Higher income lawyers were also more likely to disagree that solicitation was necessary to build a practice than lower income lawyers.").

${ }^{183}$ Survey evidence reveals that accountants with fewer years of experience are "somewhat more permissive in their activities toward direct uninvited solicitation." AICPA REPORT, supra note 42, at 11 . Telser also finds that in manufacturing industries newer products are advertised more heavily than those that have been on the market longer. See Telser, Advertising and Competition, 72 J. PoL. Econ. 537, 541-51 (1964).

184 See Hazard, Pearce \& Stempel, supra note 16, at 1094-95. 
therefore, advertising and other promotion offer more valuable means of communicating their location and availability. More experienced professionals with greater investments in reputation capital have less need for these promotional techniques.

One important result of the promotional bans traditionally imposed by the state bars, then, has been a competitive tilt in favor of larger firms as well as more experienced, higher-income lawyers generally. In its empirical study of promotional restrictions on lawyers the Federal Trade Commission recognized that

[i]nformative advertising also tends to lower the equilibrium price by making the entry of new firms into the market easier. An important part of a firm's reputation is the extent of consumer awareness that the firm is in the market. When new firms are unable to advertise, it takes consumers a much longer time to learn by word-of-mouth about their presence. The new firms are kept at a competitive disadvantage during the time that consumers are less aware of their presence than of the older and more established firms. During this period, the new firms will make lower profits. Potential entrants can be effectively discouraged by the prospect of an extended period of subnormal profits. ${ }^{185}$

The Supreme Court has also noted that advertising bans can operate as barriers to the entry of less established lawyers. ${ }^{186}$ From the evidence presented in this section, it should be clear that nonadvertising promotional bans have precisely the same effect. ${ }^{187}$

The competitive implications of banning promotional inputs help explain a related phenomenon: large firms have vigorously opposed ending bans on advertising and solicitation despite the fact that they seem to have less interest in doing either. This seeming anomaly has been ascribed to an altruistic concern that promotion degrades the esteemed standing of the profession as a whole. ${ }^{188}$ But as long as competing firms differ in their use of promotional techniques, it is precisely

186 FTC STAff RePort: Access to Legal SeRvices, supra note 157, at 82.

${ }_{186}$ See Bates v. State Bar of Arizona, 433 U.S. 350, 378 (1977); supra text accompanying note 30 .

${ }^{187}$ As noted above, Justice Marshall has observed the uneven burden a solicitation ban imposes: "[T] he Disciplinary Rules against solicitation fall most heavily on those attorneys engaged in a single-practitioner or small-partnership form of practice-attorneys who typically earn less than their fellow practitioners in larger, corporate-oriented firms." Ohralik v. Ohio State Bar, 436 U.S. 447, 475 (1978) (Marshall, J., concurring) (footnote and citation omitted); see supra note 80 and accompanying text.

${ }^{188}$ See Note, Profession's Duty, supra note 144, at 1203-04. 
those firms that would use banned inputs the least that stand to gain the most from continuing the ban. ${ }^{189}$ The losers are firms that would . use outlawed inputs most, that is, smaller firms. As one commentator has asserted, "The greatest testimonial to the success of advertising has been the geometric growth of small firms into large enterprises in the few years since Bates."180

Law firms need not be direct competitors for large firms to gain from continued promotional prohibitions. According to the model presented in this section, ending promotional bans would cause lawyers to reduce pro bono and other "public interest" activities and substitute more advertising, solicitation and referral payments as means of attracting business. A significant reduction in pro bono activity would have a profound effect on the legal profession. By donating so much of their time to "deserving" individuals and causes, lawyers increase the prestige of the entire bar. Sociologists who have studied the legal profession remark on this great willingness of lawyers to undertake altruistic activities that enhance the reputation of the bar as a whole. ${ }^{181}$ More importantly perhaps, the considerable amount of pro bono and other charitable work adds weight to lawyers' long-standing claim that theirs is a service "profession," not merely a "business."

188 The largest and smallest firms in the legal profession may not compete with one another. The former serve almost exclusively a business clientele, whereas the latter serve mostly individuals. See United States Dep't of Commerce, 1977 Census of SERvice INDUSTRIEs 52 (Table 9) (1981). For example, one can extrapolate from Silberman's data to find that only $22 \%$ of the firms with 13-19 lawyers, compared to $76 \%$ of the sole practitioners, report that their primary clients are individuals. See S. Silberman, supra note 120, at 88 (citing United States Census Bureau figures). Another study divides legal practices into three types, according to whether they provide "primarily individual" legal services, "primarily standardizable" services, or a combination of both. See Hazard, Pearce \& Stempel, supra note 16, at 1101-02. Although law firms in the first two categories do not usually compete with each other, the mixed-service firms do compete with the firms providing standardizable services. This fact, the authors assert, explains the opposition to promotion in the profession:

Advertising would permit growth of primarily standardizable firms, and these firms would then begin to compete for clients who would otherwise patronize mixed service firms. As a result, mixed service practitioners would like to prevent advertising. Because mixed service practitioners probably constitute a majority of current legal service producers, and because they have correspondingly great power in the organized bar and in the political system at large, these practitioners have presented an influential opposition to lawyer advertising.

Id. at 1110 (footnotes omitted).

${ }_{180}$ Attanasio, supra note 9, at 523, 528-29 \& nn.277-81.

191 See T. PARsons, A Sociologist Looks at the Legal Profession, in Essays IN SOCIOLOGICAL THEORY 370, 384 (1954).

192 See, e.g., H. Drinker, LEGAL ETHICs (1953) (reviewing the various obligations lawyers have to the bar, the courts, their clients and their peers). Hazard, Pearce and Stempel have drawn attention to an effect of viewing law as a profession: 
accepted distinction may explain traditional legislative willingness to allow lawyers to ban forms of promotion and otherwise regulate themselves. ${ }^{193}$ Today, while defending themselves against the charge that self-regulation leads to anti-competitive cartelization, lawyers can point to the amount of time they spend helping others as evidence that they are members of a profession, entitling them to special treatment under the antitrust laws. ${ }^{194}$

Although the benefits of the public's perception of altruistic attorneys and the enhanced business/profession distinction accrue to the bar in general, the costs of pro bono work are not evenly distributed. One would predict from the model presented here that the costs fall more heavily upon smaller firms, less experienced lawyers and lower-income attorneys who must substitute more charitable work for the banned promotional input. In fact, the ratio of pro bono hours to all hours worked is higher for lawyers in small firms than for those in large

The legal profession is understandably reticent to acknowledge this tension between [the] ideal [of law as a profession] and [the] reality [of law as a business]. One means of avoiding the unpleasant implications of this tension is to minimize overt participation by lawyers in activities, such as advertising, that suggest that effective legal assistance is bought and sold.

Hazard, Pearce \& Stempel, supra note 16, at 1112-13 (footnote omitted).

${ }_{103}$ Two justices of the Supreme Court believe that law is a profession and would permit a state greater leeway in restricting lawyer promotion than if law were a business. See Zauderer v. Office of Disciplinary Counsel, 105 S. Ct. 2265, 2295-96 (1985) ( $O$ 'Conner, J. and Rehnquist, J., concurring in part and dissenting in part). For a list of cases rationalizing advertising restrictions on the ground that law is a profession, not a business, see Note, In Re R.M.J.: The Scope of Lawyer Advertising Expands, 1983 UTAH L. REV. 99, 100 n.16.

104 In defending against price-fixing charges arising from the use of minimum-fee schedules, the Fairfax County, Virginia Bar unsuccessfully sought exemption from the antitrust laws by describing law as a "profession" and claiming that "enhancing profit is not the goal of professional activities; the goal is to provide services necessary to the community." Goldfarb v. Virginia State Bar, 421 U.S. 773, 786 (1975). Although the defense did not succeed in that case, the Supreme Court did agree that "professions" differed from other businesses: "The public service aspect, and other features of the professions, may require that a particular practice, which could properly be viewed as a violation of the Sherman Act in another context, be treated differently." Id. at 788-89 n.17; accord National Soc'y of Professional Eng'rs v. United States, 435 U.S. 679, 696 (1978) (reaffirming that professional services may differ significantly from other businesses); Arizona v. Maricopa County Medical Soc'y, 457 U.S. 332, 348 (1982) (maintaining the business/profession distinction, but holding it inapplicable to the defendant doctors).

More recently, a Federal Trade Commission administrative law judge pointed with approval to the business/professional distinction in dismissing an antitrust complaint against an association of trial lawyers charged with illegal price-fixing and boycotts. In re Superior Court Trial Lawyers Ass'n, No. 9171, slip op. (FTC Oct. 18, 1984). It remains in the professions' interests, therefore, to encourage activities perceived as public service. But see Comment, Antitrust and the Professions: Where Do We Go from Here?, 29 VILL. L. REv. 115, 145-49 (1984) (predicting that courts will no longer treat professionals differently under the antitrust laws). 
firms. ${ }^{195}$ As members of the bar, large-firm lawyers benefit from the increased pro bono work other lawyers undertake to compensate for the banned input.

\section{Predation Through Promotional Restrictions}

To the extent that promotional restrictions in the bar disadvantage some firms while favoring others, they are predatory. Considerable literature and case law have developed on the ways firms can use predatory pricing to force rivals out of business in order to obtain market power for themselves. ${ }^{186}$ Verifiable instances of predatory pricing have been far fewer than the volume of writing on the subject would suggest, ${ }^{197}$ but the tactic of below-cost pricing to drive competitors from the market has nonetheless been used. ${ }^{198}$ If competition can be reduced by the forced exit of rival firms, the surviving predator can raise prices and try to recoup earlier losses with monopoly profits. Predatory pricing has risks, however, because it requires the predator to incur a certain loss in the present with no guarantee that there will be future gains, or that any such gains will suffice to cover the initial loss.

The apparent benefit of promotional input restrictions to lawyers in more established, larger firms raises the question whether some groups in the bar use promotional constraints predatorily to increase competitors' costs. Predatory cost increases have been less exhaustively discussed in the literature than predatory pricing. ${ }^{199}$ But the two are related. If a predator can increase competing firms' costs, those firms must increase prices and so lose sales. If competitors' costs can be raised significantly so that enough sales are lost, competitors may even be forced out of business. Forcing cost increases on rivals thus works like

195 See Handler, supra note 145, at 1392 (finding that amount of pro bono work is higher for sole practitioners than for the average lawyer in larger firms). For example, while $32.6 \%$ of sole practitioners repori that more than $10 \%$ of their total hours were spent in public-interest work only $10 \%$ of larger-firm lawyers do that much public-interest work. Id.

100 The most celebrated case is doubtless Standard Oil Co. v. United States, 221 U.S. 1 (1911).

107 For a discussion of the theoretical problems with predatory pricing and for citations to numerous empirical studies questioning the frequency of the practice, see $\mathrm{K}$. Clarkson and R. Miller, Industrial Organization: Theory, Evidence and Public Policy 255-57 (1982).

188 For discussion of one apparently successful episode of predatory pricing, see Yamey, Predatory Price Cutting: Notes and Comments, 15 J.L. \& EcoN. 129, 137-42 (1972).

${ }^{109}$ Several economists have developed elements of a theory of cost predation. See Salop and Scheffman, Raising Rivals' Costs, AM. Econ. REv., May 1983, at 267 (Papers and Proceedings); Oster, The Strategic Use of Regulatory Investment by Industry Sub-Groups, 20 ECON. INQUIRY 604, 610-12 (1982). 
predatory pricing, because the object of both is to reduce competition by forcing competitors out of the market. But cost predation has one clear advantage over predatory pricing: it does not require the predator to incur short-run losses before reaping any longer-run gains. Competitors bear all the losses, while the gains accrue immediately to the predator that can force up its rivals' costs.

Cost predation has disadvantages relative to predatory pricing, however. It is easy, albeit painful, to cut one's own price below costs, but firms generally have no means of increasing their competitors' costs. They must convince an outside party with some power over the industry to impose the costs. This outside agent could be Congress, a union, a government agency-or a self-regulating professional association.

Facially neutral input restrictions imposed on an entire profession may be a more subtle form of predation than predatory pricing (and so may be more defensible in court). But cost predation can work only if: (1) one industry group is able to persuade an outside agency to impose cost-increasing restrictions, and (2) a significant difference exists among firms in their use of the restricted input. ${ }^{200}$ When these two conditions hold, input cost predation becomes more than just a theoretical possibility. ${ }^{201}$

200 In one commentator's words:

As long as there is some initial difference among firms in an industry, different firms in that industry may push for regulations which increase the relative rate of return to their peculiar characteristics. Indeed, a firm may even encourage passage of a regulation which reduces industry demand or increases industry costs. The firm may encourage such regulations because they differentially damage its rivals, and thus rearrange market shares at the same time they reduce the total market. Tó go one step further, the firm may even encourage a regulation which lowers its short-term profits if that regulation simultaneously reduces the ability of its rivals to compete effectively.

Oster, supra note 199, at 606.

201 The use of input restrictions for predatory purposes is illustrated by the events culminating in United Mine Workers v. Pennington, 381 U.S. 657 (1965). A labor union and one group of coal producers conspired in collective bargaining to increase industry wages in order to disadvantage another group of employers. On its face, the collective agreement was neutral: wages were set higher for all firms, including the conspiring producers. But there was considerable variation in firm size, and labor used per ton of coal produced was greater among smaller firms. A higher union wage was an attractive predatory strategy for larger firms, because they were the less labor-intensive producers. See Williamson, Wage Rates as a Barrier to Entry: The Pennington Case in Perspective, 82 Q.J. EcoN. 85, 90-98 (1968). Williamson notes that

the sine qua non for wage premiums even to be seriously contemplated is that [there be] differences in technology between large and small scale firms . . . . Most important, the labor/capital ratio must be larger for the small scale operators. If differences in labor/capital ratios between scales are insignificant, the incentives to influence the condition of entry 
Because law firms do differ in their use of promotional inputs, the question must be posed whether the bar's promotional restrictions are actually designed to benefit some lawyers at the expense of others. Figure 2 demonstrates that regardless of state bars' motivations in imposing promotion restrictions, the effect is to penalize small firms and their clients. If one may infer intent from effect, one would surmise that intentional cost predation has truly been responsible for the restrictions. As Stigler says, "The announced goals of a policy are sometimes unrelated or perversely related to its actual effects, and the truly intended effects should be deduced from the actual effects." ${ }^{202}$ At a minimum, because some firms stand to gain from the restrictions, one must consider the possibility that anticompetitive gain rather than quality concerns or avoidance of deception is a substantial reason for the bars' traditional prohibitions on promotion. The question is of paramount importance for the commercial speech cases, of course. If potential deception is merely a pretext for the restrictions on solicitation, trade names and other nonadvertising speech, there is less reason to deny

through the use of wage premiums are correspondingly attenuated.

Id. at 98 .

Several studies have found other instances of predatory increases in competitors' costs via input restrictions. See, e.g., Maloney \& McCormick, A Positive Theory of Environmental Quality Regulation, 25 J.L. \& Econ. 99 (1982). Maloney and McCormick examined federal restrictions on the use of polluting or hazardous inputs, and found that an input constraint affects firms' wealth differentially, depending on the amount of the input used in firms' production. Id. at 117,122 . They concluded that favored producers may even work with environmental or health groups, not so much to reduce pollution or health problems, but to impose costs on disfavored industry rivals. Id. at 121-22. Other environmental regulations have made it more difficult for small plants to compete with large rivals. See Pashigian, How Large and Small Plants Fare Under Environmental Regulation, Regulation, Sept.-Oct. 1983, at 19. Another study explains English child-labor laws as a device to transfer wealth to firms using less child labor than their competitors. See Marvel, Factory Regulation: A Reinterpretation of Early English Experience, 20 J.L. \& EcoN. 379, 380. (1977). Similarly, state maximum-hour statutes on the employment of women apparently benefited males and other labor groups at the expense of women, rather than protecting women's health. See Landes, The Effect of State Maximum-Hours Laws on the Employment of Women in 1920, 88 J. Pol. ECON. 476 (1980).

One researcher has found an instance of predatory behavior in legal constraints on the use of promotional inputs. See Coase, Payola in Radio and Television Broadcasting, 22 J.L. \& Econ. 269 (1979). Coase finds that differences in the type of music sold by record companies led to the banning of "payola" in the broadcast industry. These differences had made payola more useful to some firms than others. Payola was especially valuable in promoting "rock and roll." Its use in the 1950's enabled smaller, independent companies that produced "rock and roll" to make substantial inroads on the market shares of the major record companies, which sold more traditional music. These latter firms were the ones that took the lead in having Congress outlaw payola in 1960.

${ }^{202}$ Stigler, Supplementary Note on Economic Theories of Regulation, in THE Citizen and THE State 137, 140 (1975) (emphasis deleted). 
these promotional techniques the constitutional protection accorded advertising.

Though the anticompetitive effect of promotional restrictions is clear, there is insufficient evidence at this point to resolve conclusively the question of what truly motivates state bars to outlaw certain promotional inputs. It seems unlikely that predatory motives underlay the original bans on promotion, because law firms were far more homogeneous and thus more equally affected when the first ABA Canons of Professional Ethics were adopted in $1908 .{ }^{203}$ The significant disparities in law-firm size now observed ${ }^{204}$ did not develop until the 1920 's. ${ }^{205}$ But the fact that law firms today do differ considerably in their use of promotional inputs means that the courts should be mindful of the unequal burdens that promotional input restrictions impose and should at least consider whether self-interest rather than the public interest explains the bars' reluctance to end the restrictions.

The characterization of bars as motivated by gain for some of their members contrasts sharply with the view offered by some of a benevolent, public-spirited bar genuinely concerned with problems of professionalism and consumer deception. ${ }^{208}$ But it coincides with a growing perception among those studying the organized bar more closely who find that the bar represents the interests of some lawyers at the expense of others. ${ }^{207}$ Many lawyers find that the issue in state bar regulation,

203 Canon 27 stated that "solicitation of business by circulars or advertisements, or by personal communications, or interviews, not warranted by personal relations, is unprofessional." Canons of ETHICs Canon 27 (1908), reprinted in AMERICAN BAR Foundation, Opinions of the Committee on Professional Ethics 75 (1967).

204 Just under one-half of all lawyers in private practice are sole practitioners, according to the most recent data. See AMERICAN BAR Found., The 1971 LAWYER Statistical REPORT 15 (Table 7) (1972). At the same time, large firms of even hundreds of lawyers are increasingly prominent. See Cantor, Law Firms Are Getting Bigger . . . And More Complex, 64 A.B.A. J. 215 (1978).

${ }^{208}$ See J. Carlin, supra note 120 , at 19. Carlin notes that "[u]ntil the end of the nineteenth century there were probably no firms with more than half a dozen lawyers.... The large firm as we know it today did not appear until the twenties .... Id. (footnote omitted).

${ }_{208}$ See, e.g., Boden, Five Years After Bates: Lawyer Advertising in Legal and Ethical Perspective, 65 MarQ. L. Rev. 547, 554 (1982). Boden argues that the bar has based its opposition to changes in promotional rules not on economic interests, but on a "genuine concern for the preservation of professional standards," "worry concerning the impact of advertising overhead in the cost of legal services," fear of approval of general solicitation and rejection of "a long held and deeply rooted aversion to the commercialism which advertising epitomizes." Id.

${ }_{207}$ See, e.g., J. AUERBach, UneQUal Justice: Lawyers and Social Change IN MODERN AMERICA 50 (1976) (arguing that in the early 1900's, ethics rules were "applied by particular lawyers to enhance their own status and prestige"); L. PATTERson \& E. Cheatham, The Profession of Law 45-46 (1971) (recognizing the possibility of bar associations being used as agents of one group to oppress another); Freedman, Advertising and Soliciting: The Case for Ambulance Chasing, in Verdicts on 
including restrictions on promotional inputs, has not been the attorneyconsumer relation as much as a large-firm/small-firm question. ${ }^{208}$ For them, the only meaningful way to understand the bar's traditional prohibition against the promotional inputs of greatest use to smaller firms "is as a complex and heretofore successful conspiracy in restraint of trade." 209 Finally, the depiction of promotional restrictions in the professions as predatory is consistent with the widespread view that many activities of the licensing professions, though typically justified as protecting consumers, really are designed more to protect professionals. ${ }^{210}$

LAWYeRS 94, 96-97 (R. Nader \& M. Green eds. 1976) (stating that the principle purpose of bar anti-solicitation rules is to reduce competition among attorneys); see also Cappell \& Holliday, Professional Projects of Elite Chicago Lawyers, 1950-1974, 1983 AM. B. Found. RESEARCH J. 291, 338 (quantitative study showing that once a group of lawyers attained membership on board of Chicago Bar Association, it "pursued its specialized interests").

Abolition of unified bars has even been urged, partly because of their inability to reconcile conflicting interests among different factions of lawyers. See Schneyer, The Incoherence of the Unified Bar Concept: Generalizing from the Wisconsin Case, 1983 AM. B. Found. Research J. 1. The validity of the unified bar concept is beyond the scope of this article. It is appropriate, however, to note that to many the real explanation for the existence of integrated bars lies in the benefits integration offers, not for the public, but for lawyers themselves. See, e.g., Sorenson, The Integrated Bar and the Freedom of Nonassociation-Continuing Siege, 63 NEB. L. REV. 30, $36-38$ (1983). The benefits to lawyers may explain why "[u]p to 1950 the only thoroughgoing activity of the organized profession with reference to its own housekeeping was the drive for the 'integrated bar." "J. Hurst, The Growth of American Law: The Law Makers 365 (1950).

${ }_{208}$ See Schuchman, supra note 111, at 245-46.

209 J. Lieberman, Crisis at the Bar 98 (1978).

210 See Gellhorn, The Abuse of Occupational Licensing, 44 U. CHI. L. REv. 6, 25 (1976) ("Only the credulous can conclude that licensure is in the main intended to protect the public rather than those who have been licensed or, perhaps in some instances, those who do the licensing.").

As with integration of the bar, see supra note 207 , the interplay between occupational licensing and promotional bans in the professions lies beyond the scope of this article. It is interesting, however, to note that despite claims that licensing is needed to protect consumers from substandard work studies have failed to find any systematic relation between licensing and quality of goods and services. See Hogan, The Effectiveness of Licensing: History, Evidence, and Recommendations, 7 L. \& HuM. BEHAv. 117 (1983); see also Carroll \& Gaston, Occupational Licensing and the Quality of. Service: An Overview, 7 L. \& HuM. BEHAv. 139 (1983) (concluding that in general occupational licensing in the professions results in better quality for some consumers, but not for society as a whole). Except for licensed professionals themselves, few would quarrel with Gellhorn's assessment that occupational licensing is merely occupational protectionism. See, e.g., Benham, The Demand for Occupational Licensure, in Occupational Licensure and Regulation 13, 23-24 (S. Rottenberg ed. 1980); Smith, Production of Licensing Legislation: An Economic Analysis of Interstate Differences, 11 J. LEGal STUD. 117, 125 (1982). The scholarship of at least a generation has consistently concluded that licensure primarily benefits the licensee rather than the public. See, e.g., M. Friedman, Capitalism and Freedom 137-60 (1962); W. Gelihorn, Individual Freedom and Governmental Restraints 105-51 (1956); Rottenberg, The Economics of Occupational Licensure, in AsPECTS OF LABOR ECONOMICs 3, 3-14 (1962). But skepticism about the stated public-interest purposes of 
Geoffrey Hazard and his co-authors pose and answer the question succinctly: "If advertising by attorneys is beneficial for consumers . . . why has the bar resisted it? The most obvious explanations reflect the structure of economic and political interests within the bar."211

In summary, the Court's commercial speech cases largely overlook the actual reasons for which, some observers feel, state bars impose promotional restrictions. Use of restrictions to disadvantage one's competitors goes essentially unconsidered in the cases. Instead, the focus is on the bar's claims about how much truthful information consumers can expect to receive. The issues of competition and consumer information are not unrelated, however. The more lawyers can compete by promoting themselves, the lower prices will be and the more information consumers will have. Moreover, the information facet of commercial speech may be quite secondary in the bar's regulation of promotional inputs. As Christensen has somewhat acerbically observed, "Lawyers' attitudes toward advertising generally depend upon whether they have a satisfactory client base. Those with well-established practices often find advertising crass if not unethical. Those without such a client base see a professional obligation to make legal services available to all segments of society through advertising."212

The use of promotional restrictions to advance some groups' interests at the expense of others is not limited to to the self-regulatory professions. ${ }^{213}$ The potential for predatory abuse in regulating promotion suggests, however, that the link between stated purpose and actual intent should be examined more carefully in cases involving promotional restrictions in the professions. To repeat, it is not necessary to believe that the professionals' motives are anticompetitive to appreciate that the

licensing goes back at least as far as Adam Smith. See Stigler, Occupational Licensure for Economists?, in OCCUPATIONAL LICENSURE AND REGULATION, supra, at 348, 349-50. In light of the centuries of disinterested inquiry concluding that occupational regulation helps primarily the regulated, the Supreme Court's unquestioning acceptance of professionals' arguments justifying promotional bans seems all the more remarkable.

211 Hazard, Pearce \& Stempel, supra note 16, at 1110.

212 Christensen, supra note 12 , at 619.

213 See Metromedia, Inc. v. City of San Diego, 453 U.S. 490 (1981). In Metromedia the Court held San Diego's restrictions on billboard advertising unconstitutional. According to the plurality, the regulations violated the first amendment because they prohibited all billboards containing noncommercial speech while only partially prohibiting billboards containing commercial speech. See id. at 512-17. Although the Court did not consider the possibility, one commentator has argued that the restrictions were "unrelated ... to [their] avowed purposes of increasing traffic safety and protecting scenic beauty" but instead favored some firms at the expense of their competitors. See Leffler, The Prohibition of Billboard Advertising: An Economic Analysis of the Metromedia Decision, 1 S. CT. Econ. Rev. 113, 128 (1982). 
results of their promotional restrictions must be. Even if the bar acts for the best of motives, genuinely concerned about consumer deception rather than about aggrandizing some lawyers at the expense of others, the result must be damage to competition as long as attorneys differ in their use of the outlawed input. There is, in short, no way to avoid the competition issue, even if the more dire accusations about the bar's motives are rejected.

\section{E. Constitutional Implications}

It might be argued that considerations of competition can be ignored as secondary in the commercial speech cases, which concern matters of constitutional rather than antitrust law. The argument fails, for two reasons. First, as discussed above, the commercial-speech variant of the first amendment rests explicitly on economic rather than more traditional free-speech criteria. ${ }^{214}$ Second, recognition of the differential impact that promotional restrictions have on lawyers raises a constitutional issue at least as important as the commercial speech doctrine: the due process requirement that one's property interest not be adjudicated by those who have an economic stake in the outcome.

The leading case is Gibson v. Berryhill. ${ }^{215}$ In Gibson, the Alabama Optometric Association filed with the State Board of Optometry charges of unprofessional conduct against optometrists who operated commercial optometric departments in stores. The commercial optometrists were not members of the Association; all members of the State Board were. Alleging denial of due process, the commercial optometrists sought to enjoin the State Board proceedings. The district court granted the relief, noting that the issue was not one of actual bias, but whether there was an "indication of a possible temptation to an average man sitting as a judge to try the case with bias." ${ }^{216}$ The Supreme Court unanimously agreed:

Because the Board of Optometry was composed solely of optometrists in private practice for their own account, the District Court concluded that success in the Board's efforts would possibly redound to the personal benefit of members of the Board, sufficiently so that in the opinion of the District Court the Board was constitutionally disqualified from hearing the charges filed against the appellees.

214 See supra text accompanying notes 16-18.

216411 U.S. 564 (1973). 1971)).

${ }^{218}$ Id. at 571 (quoting Berryhill v. Gibson, 331 F. Supp. 122, 125 (M.D. Ala. 
... [A]pplying the standards taken from our cases, [the District Court] concluded that the pecuniary interest of the members of the Board of Optometry had sufficient substance to disqualify them, given the context in which this case arose. As remote as we are from the local realities underlying this case and it being very likely that the District Court has a firmer grasp of the facts and of their significance to the issues presented, we have no good reason on this record to overturn its conclusion and we affirm it. ${ }^{217}$

Notable in the Court's opinion is its willingness to recognize the "context" and the "local realities" underlying the commercial restrictions. The same economic "realities"-use of restrictions to benefit one group at the expense of another-may underlie the bar's restrictions on commercial speech. At a minimum, the data show, the result of the restrictions is to benefit one group, large firms, at the expense of another, small firms. Even if the bar is not anticompetitively motivated in promulgating its restrictions, its adjudicative enforcement makes it possible for some groups to benefit at the expense of others. The dominance of better established, larger firms in the governance of bar affairs makes due process fears all the more reasonable. ${ }^{218}$

In the Supreme Court's commercial speech cases, the due process problem of bias in adjudication has arisen only once, in Friedman $v$. Rogers, ${ }^{219}$ which arose from facts strikingly similar to those in Gibson. ${ }^{220}$ In Friedman, however, the Court did not consider the issue

${ }^{217}$ Id. at 578-79. The Court remanded the case on other grounds. Id. at 579-81.

${ }^{218}$ Large-firm domination of the bar is evidenced by the proportionately small representation of sole practitioners elected to chair state bar associations. Sole practitioners comprise almost $50 \%$ of the legal profession, see supra note 203 , but over $90 \%$ of state bar chairmen in 1982 practiced in partnerships, according to a state-by-state examination by the author of bar chairmen's firm affiliations as listed in MARTINDALE-HuBbell LAW DIREcTORY (114th ed. 1982). The percentage was practically the same in 1975, before Bates.

This domination of the bar by established and prominent lawyers is not merely a recent phenomenon. Chief Justice Burger observes that, when founded, the ABA was regarded as "an assemblage of the elite- of the Establishment." Remarks of Warren E. Burger, Dedication of the American Bar Center 1 (Aug. 5, 1984) [on file with the University of Pennsylvania Law Review]. The ABA "was an establishment-oriented organization quite satisfied with the status quo." Burger, supra note 110, at 62 .

218440 U.S. 1 (1979).

220 In Zauderer v. Office of Disciplinary Counsel, 105 S. Ct. 2265 (1985), the state's enforcement of its promotional restrictions raised a different due process issue stemming from the bar's varying theories of the case at various stages of the disciplinary proceedings. Despite the changes in the state's rationale for disciplining Zauderer, the Court held that the notice and opportunity to be heard were sufficient to satisfy the requirements of due process. See $i d$. at 2283-84. 
because Rogers sought a declaratory judgment against the Board's regulations themselves, instead of questioning the due process implications of their possibly unconstitutional enforcement against him later. ${ }^{221}$ Due. process might have been an issue in Ohralik, in which the soliciting attorney had been publicly reprimanded by the disciplinary board of the state bar (a sanction increased to indefinite suspension by the Ohio Supreme Court), ${ }^{222}$ but apparently the issue was not raised.

The fact that most commercial speech cases have arisen in the selfregulating professions suggests that the Court will eventually be presented with a case raising both first amendment and due process issues. As long as firms in the self-regulating industry are not alike in their use of promotional techniques, some potential for bias arises in enforcement of promotional restrictions. Recognition of the problems for competition that differences in input use creates should force litigants and courts to consider whether potential bias amounting to denial of due process is not at least as important as the problem of potential deception.

\section{The Deception Issue}

Absent deception, as the previous section demonstrated, prohibitions on commercial speech harm consumers and competition in a variety of ways. Promotional bans raise prices and reduce both the availability of professional services and the information provided to consumers. They also punish firms that would use more of the promotional input in question. Because the bans benefit some professionals at the expense of their competitors, serious due process questions may arise in the enforcement of the bans, in addition to the concerns for consumers and competition that the bans should elicit.

Predation may not be the reason for the bans, however. They may in fact be explained as disinterested attempts to prevent consumer deception-the rationale accepted by the Court in Ohralik and Friedman. Ineluctably, there is a feeling of déjà vu about this argument for promotional bans. Protecting quality of services was long the bar's defense for blatantly anticonsumer, anticompetitive practices such as minimum fee schedules. ${ }^{223}$ But even if promotional bans are genuinely motivated by fear of consumer deception, the Court's decisions in the nonadvertising cases, holding that merely potential deception justifies a

221 See Friedman, 440 U.S. at 18-19.

222 See Ohralik, 436 U.S. at 452-54.

223 See Note, A Critical Analysis of Bar Association Minimum Fee Schedules, 85 HARV. L. REV. 971, 982-85 (1972). 
ban on commercial speech, are incongruous. As explained in Section I, a weighing of the potential deception avoided by a ban against the benefits of allowing the commercial speech would be more logical and consistent with other commercial speech cases.

It cannot be denied that substantial deception may exist. A proper cost-benefit test might conclude that the costs of deception outweigh the benefits of allowing the speech and that no means short of a ban are available to control the deception. But the reverse may also be true. Deception may be inconsequential, and less drastic means than a ban may effectively control it.

A principal objection to the Court's analysis in the nonadvertising cases, then, is the failure to raise the questions it did consider in the advertising cases: how extensive would deception actually be if the speech were allowed and are less restrictive means available to mitigate it? These are largely empirical questions, about which the Court presented no evidence. The available data indicate, however, that deception is unlikely to be a serious problem and that many devices short of a ban, including market forces themselves, may adequately constrain it.

\section{A. The Deception Issue in Perspective}

Before the extent of deception is examined, the issue must be put in perspective. Any speech, commercial, political or, other, is potentially deceptive, because a speaker cannot prevent listeners from misinterpreting the words used. ${ }^{224}$ Even the most honest speaker cannot control completely the inferences that audiences draw from a speech. Words rarely have a single meaning, and some consumers may attach the wrong interpretation to speech that is truthfully spoken and correctly interpreted by most. ${ }^{225}$ If minimizing deception were the sole issue,

224 John Locke noted the difficulty created when "any word does not excite in the hearer the same idea which it stands for in the mind of the speaker." Locke, An Essay Concerning Human Understanding, in 35 GREAT BOOKS OF THE WESTERN WORLD 85, 286 (R. Hutchins ed. 1952). For a recent example of this phenomenon, see Fedor, Calculator Ads Show That Truth in Advertising Can Mislead, Wall St. J., Jan. 16, 1985, at 31, col. 1 .

225 Jacoby and his colleagues caution against too quickly blaming an advertiser when some consumers miscomprehend the message:

Given that the receivers of communication messages differ substantially in terms of their past experiences and present "semantic expectations," it is not surprising to find substantial levels of miscomprehension. There is no need to attribute malevolent motives to an advertiser in order to understand how receivers may misinterpret an advertising message.

Jacoby, Nelson, \& Hoyer, Corrective Advertising and Affirmative Disclosure Statements: Their Potential for Confusing and Misleading the Consumer, J. MARKETING, 
therefore, one would simply ban all speech-a patently silly solution. Yet it is the solution adopted by the professions and upheld by the Court to mitigate possible deception in the nonadvertising cases.

Deception can, and doubtless does, arise in every line of commerce and industry, yet rarely are commercial speech bans imposed. One must ask why the professions merit different treatment. Some commentators cannot find any reason: "The 'evils of unrestricted solicitation' is rhetorical overkill. Certainly a lawyer can be annoying and can overreach. People can be injured by fraudulent or misleading solicitation. But these problems are not unique to the legal profession. There is no justification for a uniquely restrictive solution."228 Bans on professional speech might make some sense if there were reason to believe that deception is a bigger problem in the professions than in other industries. There is no evidence that it is. Thus, no compelling reason exists to apply special constraints to professional promotion in the name of avoiding deception.

Indeed, there is good reason to believe that deception is less of a problem in the professions than in other lines of commerce. Professionals depend on repeat business and recommendations from others for their livelihood. Surveys show, for example, that most consumers who use lawyers locate them through recommendations of friends, relatives and the like. ${ }^{227}$ The percentages vary among sources, ${ }^{228}$ but the mes-

Winter 1982, at 61, 69. For judicial recognition of this proposition, see FTC v. Sterling Drug, Inc., 317 F.2d 669, 675 (2d Cir. 1963) (stating that most words have alternative definitions, "but if that in itself were a sufficient legal criterion [for deception], few advertisements would survive"); In re Kirchner, 63 F.T.C. 1282, 1290 (1963) (noting that people "may be misled by even a scrupulously honest claim"); see also Reich, supra note 64, at 783 ("Even the most straightforward and truthful communication may mislead those who take it too literally, give it too much credence, misunderstand its substance, or draw false implications from it.").

${ }^{226}$ Sims, Lawyer Solicitation Rules, Litigation, Winter 1981, at 22, 59. 222

The Benson Commission (in England) stated that close to half of

first-time users found their solicitors by relying on what it characterized as "personal or informal contacts." These were the recommendations of friends, relatives, neighbors, or-for $9 \%$-personal acquaintance with the solicitor or a member of his firm. Similarly, in America, $52 \%$ of first-time users and $53 \%$ of later users selected lawyers on the basis of recommendations, the vast majority of whom were relatives, friends, neighbors, fellow workers, or business acquaintances. An additional $33 \%$ of first-time users and $31 \%$ of later users knew the lawyer personally in a non-legal context.

Attanasio, supra note 9, at 521 n.225 (citations omitted).

${ }^{228}$ In contrast to the figures reported by Attanasio, id., another survey found that in choosing an attorney $58 \%$ of consumers relied on a personal acquaintance with a lawyer and 33\% used recommendations from friends. Smith \& Meyer, Attorney Advertising: A Consumer Perspective, J. Marketing, Spring 1980, at 55, 60 (Table 1). The Smith-Meyer survey is also interesting for its findings as to information sources consumers do not use. "[M]uch of the information that has been available to consumers from bar associations (referrals) and/or from attorneys in yellow pages list- 
sage is always the same: a potential client's familiarity with a lawyer and recommendations from others "dominate the selection process for personal services." 229 A lawyer in the habit of deceiving only reduces the likelihood of repeat business and favorable recommendations or referrals from past clients. ${ }^{230}$ Deception, therefore, is simply a less attractive business strategy to professionals than to other businessmen not so dependent on ongoing relationships with customers. However possible deception might be, it is not in most professionals' interest to practice it. In fact, one would predict that professionals would affirmatively seek to avoid unintended misperceptions by keeping commercial messages simple and by inserting qualifying language where necessary. ${ }^{\mathbf{2 s 1}}$

There is a second market corrective for any incentive to deceive that sellers might otherwise have. Much promotion, to use Professor Grady's term, is a "search complement." listener to get more information from other sources about the professionals who promote, rather than to rely solely on the promotional messages themselves. If professionals have deceived or disappointed others, their advertising only causes consumers to ask others about them and so speeds dissemination of information about their previous deception or shortcomings. Thus, those who have better records of satisfying consumer demands have a greater incentive to promote themselves;

ings . . . has been the least used. This suggests that bar associations have not allowed attorneys to communicate information about useful evaluative criteria." Id. at 60 .

${ }^{229}$ Smith \& Meyer, supra note 228, at 59.

${ }^{230}$ See generally Klein \& Leffler, supra note 83, at 217 (When substitutable goods exist, production of a good below consumers' quality expectations will cause consumers to cease purchasing from the deceptive producer.).

231 To the extent that the seller's future sales depend on his maintaining a reputation for reliability, he can be expected to exercise self-restraint in his claims and to invest in ways (like disclaimers and warnings) to reduce the likelihood of deception. Such a seller does not want consumers to misperceive his claims, and thereby underinvest in additional search, because any resulting consumer dissatisfaction with his product or service may harm future sales. Disappointed consumers are apt to distrust the seller's subsequent claims and may also induce family and friends to stop relying on those claims. In these situations, there is no reason for outside intervenors-licensing boards, federal regulators, or the courts in the exercise of their first amendment jurisdiction-to attempt to define a more optimal level of restraint on commercial speech.

Reich, supra note 64, at 794 (footnote omitted). This argument does not imply that no deception will occur. If deception is costly for sellers to avoid, at some point the costs of avoidance will exceed those of deception itself, and sellers will therefore not incur the costs of avoidance. But since the benefits of reducing deception in this case are less than the costs, regulatory efforts to remove any remaining deception will cost more than they are worth.

232 See Grady, supra note 125, at 227; see also Hazard, Pearce \& Stempel, supra note 16, at 1099 ("Advertising tends to cause consumers to seek information about the producer's reputation and about other consumers' direct experience with him."). 
those who have failed are more likely to remain silent. ${ }^{233} \mathrm{Far}$ from encouraging deception, promotion can actually reduce the amount of deception by encouraging consumers to learn more about other consumers' experiences-bad as well as good-with professional sellers. Knowing this, sellers who disappoint or deceive will not be the ones to advertise most.

A seller's incentive to promote deceptively, therefore, is constrained by a desire for repeat business and by the realization that promotion creates a demand for information about past performance. Sellers' incentives, however, reflect only half the process of potential deception. Deception requires not only a deceiver, but a deceived. The deception problem "can be easily exaggerated if one simply looks at the incentives of advertisers to deceive without considering the incentives of consumers not to be deceived."234 Even if a professional intends to mislead, buyers often recognize the self-interest in laudatory promotion, discount it appropriately, and seek corroboration from others who have dealt with the advertiser. ${ }^{235}$

Further, even if a promotional message initially misleads a consumer, the deception may not ultimately cause harm. ${ }^{236}$ Whether actual harm ensues depends on several factors. First, because "advertising is rarely, if ever, the only source of information about products and prices," ${ }^{237}$ a client may correct any misperceptions before harm results. Moreover, since much promotion is a "search complement," deception is even less likely to result in harm. Such promotion is intended only to convey the message that the consumer may have a problem that a professional could solve. This message seeks to induce its audience to contact a professional, at which point more informative discussions will follow concerning the exact nature of the services, their timing, and

${ }^{233}$ See Nelson, The Economic Value of Advertising, in ADVERTISING AND SociETY, supra note 175 , at 48,50 ("The consumer is right in his belief that advertised brands are better. The better brands have more incentive to advertise than the poorer brands."). For instance, those who offer better prices tend to advertise more. See infra text accompanying note 243. See generally Jordan \& Rubin, An Economic Analysis of the Law of False Advertising, 8 J. LEGAL STUD. 527 (1979) (finding that the economics of advertising indicate little incentive to deceive the consumer).

${ }^{234}$ Nelson, Advertising as Information, 82 J. Pol. Econ. 729, 749 (1974).

238 Hazard, Pearce and Stempel argue that "because the advertising information comes from an impersonal source, consumers often pay little or no attention to it. Similarly, the obviously biased source of the message encourages them to seek corroboration through other available reputation information." Hazard, Pearce \& Stempel, supra note 16 , at 1097 .

${ }_{28 s}$ The distinction between misrepresentation and harm is well recognized. A speaker may knowingly misrepresent a material fact, but only if the hearer is harmed thereby will an action for fraud or deceit lie. See Prosser and KeEton on the Law OF TORTS $\S 105$, at 728 (W. Keeton ed. 1984).

${ }^{237}$ Hazard, Pearce \& Stempel, supra note 16, at 1094 (citing sources). 
cost. In public accounting, for example, fully ninety-five percent of C.P.A. firms sign a written "engagement letter" with their audit clients specifying the terms of the auditing agreement. ${ }^{238}$ Legal clinics are likewise in the practice of using initial consultations to explain fee structures, despite the fact that previous promotion may already have imparted information on that subject. ${ }^{238}$ Even if the initial advertisement or solicitation contained misleading information about a term of the professional service contract, subsequent negotiations between professional and client could dispel any misperception before substantial harm resulted. ${ }^{240}$

Even if some speech genuinely and harmfully deceives, the net effect of permitting commercial speech may actually be to reduce total consumer misperceptions. Consumers are apparently quite ignorant about important aspects of professional services. For instance, in the mid-1970's, the ABA Standing Committee on Lawyer Referral Service found that lawyers in over three-quarters of the eighty-five referral services reporting charged ten dollars or less for an initial half-hour consultation, and that none charged more than twenty dollars. ${ }^{241}$ At the same time, the ABA Special Committee to Survey Legal Needs found in a survey of over 2,000 individuals that most overestimate considerably the cost of such a consultation. Some thirty-five percent of respon-

238 See Van Son, Guy \& Poots, Engagement Letters: What Practice Shows, J. ACCT., June 1982, at 72, 74 (Exhibit 1). Further, those firms not using engagement letters omit them because they have "long-standing relationships with their clients" who presumably are aware of the firm's quality and fees. Id. at 76.

${ }^{239}$ See, e.g., Attorney Grievance Comm'n v. Hyatt, Nos. 83-1479 and 83-1845 (Md. Cir. Ct. April 11, 1984) (finding that any misperceptions created by a legal clinic's use of promotional brochure were cured at the initial consulation, when fees were fully disclosed and a fee agreement signed), dismissed for lack of jurisdiction, 302 Md. 683, 490 A.2d 1224 (1985).

${ }^{240}$ Relying on subsequent point-of-sale negotiations to correct any client misperceptions may, however, not always be successful. In Zauderer v. Office of Disciplinary Counsel, 105 S. Ct. 2265, 2271-73 (1985), for example, the Dalkon Shield advertisement mentioned that cases would be handled on a contingency basis, but was attacked for failing to inform potential clients that they would still be liable for costs, as opposed to legal fees, in the event of an unsuccessful action. The Court upheld the reprimand of Zauderer for failing to include information about costs. See id. at 228182. Yet Zauderer had entered into a comprehensive retainer agreement with his clients that specified the details of the contingency fee and explicitly stated that "out-of-pocket costs incurred or advanced" by Zauderer's firm must be borne by [the client]." Id. at 2288 n. 6 (Brennan, J., concurring and dissenting). In addition, this retainer agreement explained the recoverable sums to which the contigency fees would be applied. Even if the potential for deception from the advertisement was as clear as claimed, see id. at 2283 , the majority did not explain why the disclosures at the point of sale were any worse than disclosures deemed necessary in the ad itself, or how consumers were harmed by having them in the agreement rather than the advertisement.

${ }^{241}$ ABA Consortium on Legal Services \& the Public, Alternatives, Jan. 1976, at 17 (special issue). 
dents making an estimate believed the charge would be twenty-one to thirty dollars, and forty percent estimated the cost to be thirty-one dollars or more. ${ }^{242}$ The fact that prices are actually lower than what prospective clients believe is precisely the sort of information that professionals have every incentive to communicate. Not surprisingly, the empirical evidence from the professions, including law, shows that it is those professionals selling at lower prices who advertise more. ${ }^{243}$ If professionals are able to promote lower prices, existing misperceptions that arise from the paucity of commercial information will be dispelled. Even assuming arguendo that the commercial speech is deceptive to some, it will reduce misperceptions that others already have. Any defensible evaluation of deception in commercial speech must tally old errors corrected, not just new ones created. ${ }^{244}$

Finally, even if deception were a major problem in the professions, it does not follow that banning promotion would lessen the incidence of deception. Indeed, it is at least equally plausible that the correlation between promotion and deception is negative, not positive. Vigorous promotion increases consumer information and lowers the cost of shopping for a "second opinion." Promotion also imprints sellers' names and their services more indelibly in consumers' minds. Increased identification lowers the attractiveness of deception for fear of discouraging

${ }^{242}$ Id.; see also B. Curran, The Legal NeEds of the Puburc 234-36 (1977) (finding that consumers who had never used lawyers' services were more likely than previous users to express the opinion that lawyers charged more for their services than they were worth).

${ }^{243}$ Optometrists who advertise have lower prices than those who do not. See FTC STAFF REPORT: ADVERTISING RESTRICTIONS IN OPTOMETRY, supra note 40, at 195. Three studies find that prices charged by lawyers who advertise are less than those who do not. The FTC study of lawyer promotion found that

in almost every case where there are specific findings, the results showed that attorneys who advertised a specific service tended to provide that service to the public at a lower price than both those attorneys who did not advertise at all and those attorneys who did not advertise the specific service.

FTC Staff Report: Access to Legal Services, supra note 157, at 125. Other researchers found similar results in a survey of Phoenix attorneys. See Cox, DeSerpa \& Canby, Jr., Consumer Information and the Pricing of Legal Services, $25 \mathrm{~J}$. Indus. EcoN. 305, 315 (1982). Legal clinics that advertise heavily also have fees lower than the mean. See Muris \& McChesney, supra note 41, at 195-96.

${ }^{244}$ According to Professor Baird:

[I]dentifying a cost of an action is not sufficient reason to decide not to take the action. We must compare that cost . . . with the benefit we expect to derive. If, for example, permitting advertising would reduce the cost and improve the quality of professional services for most consumers, advertising perhaps should be permitted even though some gullible consumers may be made worse off.

C. BAIRD, supra note 162 , at 22 . 
repeat sales and favorable recommendations. ${ }^{245}$

\section{B. The Extent of Deception}

With all that said, what is the extent of actual deception from commercial speech? There are few precise data on this subject. But the data available suggest unanimously that deception in the professions is not a large problem. A survey taken in Florida three years after attorney advertising was allowed found no correlation between firms that advertised and malpractice claims. ${ }^{246}$ A recent survey of state regulatory agencies undertaken for the Federal Trade Commission found that there was little or no problem with false advertising by doctors. ${ }^{247}$ In fact, some empirical evidence suggests that more promotion is associated with less deception. In jurisdictions free of advertising bans and restrictions on commercial practice, optometrists are less likely to prescribe new eyeglasses unnecessarily. ${ }^{248}$

In addition to this evidence, studies have repeatedly found that consumers do not view the possibility of their being deceived by promotion as nearly the problem that professionals themselves claim it to be. A 1979 survey found that among respondents expressing an opinion, consumers favored allowing doctors to advertise by almost four to one. ${ }^{249}$ Of particular interest are consumer perceptions of why professionals impose restrictions on commercial speech:

Professionals ... say that by restricting advertising, they are trying to protect the public against unscrupulous

245 Ferguson has argued that

with expenditures on advertising, the firm signals to consumers that it is investing substantial sums to establish a reputation. Sales will cover these costs only if the firm provides, and continues to provide, a good product. Consumers choose heavily advertised brands as better buys because they know the costs of cheating on quality are likely to be greater to these firms, especially since most heavily advertised products are frequently purchased items which depend on repeat sales.

Ferguson, Introduction to C. BAIRD, supra note 162, at 3. For a more formal economic analysis of the correlation between advertising expenditures and product quality, see Klein \& Leffler, supra note 83, at 629-33.

${ }_{246}^{24}$ See Survey: Ads Not Drawing Malpractice Claims, 67 A.B.A. J. 25 (1981).

247 See Braun \& Braun, Advertising Health Care Professionals: Problems, Solutions and Benefits, in Advertising by Health Gare Professionals in the 80's: Proceedings of a National Symposium Sponsored by the Federal Trade CoMmission 87 (1985).

${ }^{248}$ See -FTC STAFf Report: AdVERTISIng Restrictions In Optometry, supra note 40 , at 21 (Table 8 ).

240 Shapiro \& Bohmbach, Much Ado About Nothing Much? What's the Fuss, Consumers Ask, ADVERTISING AGE, Dec. 24, 1979, at S-4 (opinion survey of 706 consumers on advertising by lawyers and physicians). 
practices. Consumers, on the other hand, believe that "safeguards" professionals want are designed to protect the professional, not the public.

In our surveys, eight of ten consumers believed that advertising serves a useful purpose. The respondents were also aware that advertising today is heavily monitored by both industry and government agencies. Many thought that is all the protection they need. ${ }^{250}$

Other surveys in law and medicine similarly reveal that consumers want more information from professionals rather than protection against evils that only professionals seem to see. ${ }^{251}$

It is sometimes alleged that consumers of legal services are too ignorant to know whether they had received quality services and would not know if they had been deceived. But researchers have tested this contention also, and found it unsupported. ${ }^{\mathbf{2 5 2}}$ Consumers have shown themselves remarkably adept at extracting truthful information about lawyers from advertisements, even when the advertisement does not explicitly include the information. ${ }^{253}$ There is simply no reason to believe

$250 I d$. at $\mathrm{S}-5$.

261 See, e.g., Dyer, Clients and Lawyers at Odds on Advertising, 2 NEw DIREcTIONS IN Legal Services 146, 148-50 (1977); Dyer \& Shimp, Reactions to Legal Advertising, J. Advertising Research, Apr. 1980, at 43,50; Miller \& Waller, Health Care Advertising: Consumer vs. Physician Attitudes, J. AdverTISING, Fall 1979, at 20, 22; Patterson \& Swerdlow, Should Lawyers Advertise? A Study of Consumer Attitudes, 10 J. ACAD. Marketing ScI. 314, 322 (1982); Shapiro \& Bohmbach, supra note 249 , at $S-5$.

252 In one study, consumers of legal services were asked to compare a legal clinic that advertised heavily with traditional law firms that did not advertise. See Muris \& McChesney, supra note 41, at 197-201. Using seven different measures of professional performance, consumers rated the clinic-advertiser superior. In addition to reporting these subjective evaluations, the study then developed an objective measure of quality by comparing the results of employing the clinic rather than traditional law firms in childsupport proceedings. Statistical tests showed that the clinic also provided superior service in an objective sense: the clinic obtained higher support awards for its female clients retaining custody of their children and lower required support payments for male clients (though the latter difference was not statistically significant). Thus, consumers' subjective ratings accurately reflected the objective results.

263 A controlled experiment conducted recently provides evidence in support of this conclusion. See Patterson \& Swerdlow, supra note 251. Researchers asked a sample of consumers to examine a hypothetical lawyer advertisement, consisting of a brief slogan ("What You Don't Know Can Hurt You. Be Sure."), followed by the name and address of the hypothetical attorney and the services provided. Consumers were then asked to compare a lawyer who would use such an advertisement with the "typical or average" lawyer in several respects, including age, experience, competence, and fees. The advertisement offered no information about these characteristics. Overall, survey respondents viewed a lawyer who would use the advertisement as younger, less experienced, and less established than an average lawyer. This impression is in fact true. See supra Table 4, at 89. Respondents also rated the competence of the advertising lawyer as no better or worse than that of the typical lawyer. Once again, the image conveyed 
that consumers are as easily deceived as some professionals seem to believe.

Less is known about deception in connection with solicitation or personal selling. But here again, the available evidence suggests that consumers do not view solicitation as the evil that professionals do. As with advertising, consumers see promotion as something a professional does for them, not to them. In accounting, for example, a survey found that sixty percent of business executives identified accountant "aggressiveness" in soliciting business as favorably influencing their selection of an accounting firm. ${ }^{254}$ In addition, a study of consumers in Scotland found that " $70 \%$ of those polled would welcome an unrequested offer of legal services while only $2 \%$ would resent it."2ss

Even if consumers were not so receptive to professional solicitation, there is no evidence that such solicitation leads to deception. Although the Court in Ohralik v. Ohio State $\mathrm{Bar}^{256}$ relied on the Federal Trade Commission's conclusion that door-to-door solicitation involves considerable deception, ${ }^{\mathbf{2 5 7}}$ the Commission findings to which the Ohralik opinion pointed were based on anecdotal, testimonial evidence. True, the FTC listened to a number of "horror stories" from state officials and others, but no one had any idea whether these episodes were

squares with the empirical evidence, and may even be a bit conservative. See supra notes 40-41 and accompanying text. Finally, consumers perceived the advertising lawyer to be less expensive than the average practitioner. Empirical evidence also verifies this belief. See supra note 243 and accompanying text.

${ }^{254}$ See George \& Solomon, supra note 133, at 83 (The reaction by executives "point[s] out an apparent approval of direct marketing efforts by CPA firms.").

${ }^{285}$ Attanasio, supra note 9, at 539 n.353 (citing Campbell \& Wilson, Public Attitudes to the Legal Profession in Scotland, Summary of the Research Report Presented to the Law Society of Scotland 17-18 (1973)).

258436 U.S. 447 (1978).

257 Specifically, the Court found that

[t] the detrimental aspects of face-to-face selling even of ordinary consumer products have been recognized and addressed by the Federal Trade Commission, and it hardly need be said that the potential for overreaching is significantly greater when a lawyer, a professional trained in the art of persuasion, personally solicits an unsophisticated, injured, or distressed lay person.

436 U.S. at 464-65 (footnotes omitted). The Court's reasoning is unpersuasive. Doorto-door salesmen are also "trained in the art of persuasion," probably far more intensively than lawyers. See, e.g., Burck, High-Pressure Consumerism at the Salesman's Door, Fortune, July 1972, at 70, 92 (describing sales training for door-to-door sellers of vacuum cleaners and rug shampooers). Moreover, items sold door-to-door are often those like encyclopedias, appliances, or furnishings that customers purchase infrequently and only rarely from the same individual. The potential for repeat sales therefore may not discipline sellers of these items the way it would professionals dependent on repeat sales to clients and favorable recommendations from them. Again, whatever the potential for deception, it simply may not be as much in professionals' self-interest to attempt it. See supra text accompanying notes 232-33. 
infrequent or typical. More recently, the FTC has collected statistical evidence, based on a random national sample, concerning consumer experience with door-to-door soliciting. Contrary to the FTC's original assertions, the systematic evidence indicates that deception in door-todoor selling is minimal, and that consumers who are solicited door-todoor are overwhelmingly satisfied with their purchases. ${ }^{258}$ Thus, consumer experience with door-to-door sales suggests that deception caused by in-person solicitation is a far smaller problem than one might have thought.

There is no evidence on how solicitation bans affect the extent of deception in the professions. In the absence of such evidence, the Supreme Court's refusal to impose upon state bars the burden of justifying their bans becomes all the more crucial. The American Institute of Certified Public Accountants abandoned its ban on solicitation in 1979 under threat of antitrust action by the Department of Justice, precisely because "the absence of persuasive evidence that direct uninvited solicitation by CPA's is likely to lead to false or misleading claims or oppressive conduct [makes] it unlikely that the ban would be upheld in a judicial proceeding."258 Absence of evidence was no problem for the state bar in Ohralik, however. Had the state truly had the burden of showing that deception via solicitation was a serious problem in Ohio, one wonders to what it would have pointed.

\section{G. Less Restrictive Alternatives}

The arguments presented in this section thus far do not deny that some deception may occur. But a ban is a blunt weapon for regulating whatever deception exists. Most commercial speech apparently is not deceptive, and a ban means losing useful consumer information and reducing competition. ${ }^{260}$ As the Supreme Court has recognized in the advertising cases, less restrictive alternatives to outright bans may effectively mitigate problems of deception without unduly adverse consequences for buyer information or competition. ${ }^{261}$

258 See Public Sector Research Group, Final Report of an Impact Evaluation of the CoOling-Off Period for Door-to-Door Trade Rule (1981); Walker Research, Inc., Three-Day Cooling-Off Period Trade Rule Evaluation Study (1981). These studies are discussed in McChesney, Regulation Without Evidence: The FTC's Cooling-Off Rule, J. ConTEMP. STUD., Winter 1984, at 57, 63-65.

259 AICPA REPORT supra note 42, at 2.

${ }^{260}$ As Reich has stated, "Prophylactic rules designed to prevent deception will necessarily filter out some truthful, nondeceptive speech." Reich, supra note 64, at 777. ${ }_{281}$ See supra text accompanying notes 52-56. For a recent decision striking down state restrictions on direct mail advertising, in part because less restrictive alternatives 
Although the Court did not consider whether less restrictive alternatives to banning solicitation exist, several in fact are available. First, in many states, a client may discharge his attorney at any time, without cause, regardless of any contractual relationship, and is required to pay only in quantum meruit for any services rendered. ${ }^{262}$ If the lawyer has deceived, the client may abrogate any contract with the lawyer and pay only for value received. Allowing clients to discharge their attorneys without cause and pay only for benefits conferred (net of any costs of deception, nuisance, or harassment from solicitation) would protect clients from undesirable sales tactics without impeding the flow of truly useful information. It would be, in short, a more efficient and equitable rule than a total ban on solicitation.

A second remedy for deceptive or harassing tactics is perhaps even better. Upon concluding that door-to-door selling entailed significant potential for deception, the FTG imposed a mandatory three-day "cooling-off" period on most door-to-door sales contracts. ${ }^{263}$ During this period buyers may rescind their contracts merely by notifying sellers. The bar could adopt a similar cooling-off rule for solicitations that result in contracts covering the purchase of legal services. Such a remedy would have resolved any problem in Ohralik, in which the one client subjected

were available, see Spencer v. Honorable Justices of the Supreme Court, 579 F. Supp. 880,888 (E.D. Pa. 1984).

${ }^{262}$ Quantum meruit is

[a]n equitable doctrine, based on the concept that no one who benefits by the labor and materials of another should be unjustly enriched thereby; under those circumstances, the law implies a promise to pay a reasonable amount for the labor and materials furnished, even absent a specific contract therefor.

Black's Law Dictionary 1119 (5th ed. 1979); see, e.g., Heinzman v. Fine, Fine, Legum \& Fine, 217 Va. 958, 234 S.E.2d 282 (1977). See generally Annot., 92 A.L.R.3d 690 (1979) (discussing quantum meruit recovery cases). At least 19 jurisdictions apply the rule allowing discharge of an attorney with payment only in quantum meruit. See id. at 694-96. This rule was apparently not the law in Ohio, however, at the time the Ohralik case arose. See Dombey, Tyler, Richards \& Grieser v. Detroit, T. \& I.R.R., 351 F.2d 121, 127 (6th Cir. 1965) (applying Ohio law that a full contractual contingent fee is recoverable when a client discharges an attorney without cause). Although still not the majority rule, the rule allowing liberal discharge of one's attorney with payment only in quantum meruit is described as the "modern rule," because the trend appears to be toward greater liberalization. See Casenote, 51 UMKC L. REv. 373 (1983) (discussing recent cases).

${ }_{283}$ See 16 C.F.R. $\S 429.1$ (1985). A mandatory cooling-off period is used in other contexts to remedy possible deception or "high-pressure" tactics. See Truth in Lending Act $\S 125,15$ U.S.C. $\$ 1635$ (1982) (describing the right of rescission of a consumer credit transaction involving a security interest on the principal place of dwelling); see also Gerasta v. Hibernia Nat'l Bank, 411 F. Supp. 176 (E.D. La. 1976) (recognizing the right of rescission under the Truth in Lending Act); cf. 16 C.F.R. $\S 438.2$ (1985) (addressing the rescission of vocational school enrollment contracts). 
to alleged "high-pressure" tactics attempted to rescind within a day. ${ }^{264}$ A cooling-off rule is self-enforcing: it requires only that sellers give to buyers a cancellation form and a conspicuous, written statement of buyers' rescission rights. A cooling-off rule would be a cheaper and speedier remedy for clients than the bar's grievance machinery. ${ }^{265}$

Rescission that directly combats deception, rather than a total ban that blocks even truthful speech, comports far better with the first amendment values underlying the commercial speech doctrine. In the first place, rescission is more consistent with the rationale of the advertising cases, in which the Court has required that restrictions on speech be narrowly drawn in order not to interfere with the flow of truthful information. Notably, although the FTC determined that door-to-door selling was inherently and actually deceptive, ${ }^{266}$ the agency imposed only a three-day period for rescission following supposedly deceptive solicitations. On the other hand, faced with a case in which no deception had actually occurred and in which admittedly useful information had been communicated, the Supreme Court upheld a total ban on the solicitation because of its mere "potential for harm."267 A rescission period would avoid many of the supposed evils of solicitation without loss of the benefits. Problems stemming from solicitation not remedied by a

204 "High pressure" and lack of an opportunity for reflection were arguably a problem for the passenger client, whom Ohralik visited unbidden and from whom he almost immediately obtained oral assent for his representation. But the girl and her mother attempted to rescind the agreement the next day. See Ohralik, 436 U.S. at 45152. Even a brief cooling-off period would have allowed the rescission. The other client, who drove the car, experienced no high pressure or lack of time for reflection in the first place. Before Ohralik visited her, he telephoned and then visited the client's mother, who agreed to his contacting her injured daughter in the hospital. It was her parents who later told Ohralik that their daughter had agreed to his representing her. Ohralik did not return to the hospital to have the girl sign his contingency agreement until two days later. See id. at 449-50.

${ }^{265}$ Contracts for the purchase of legal services induced by lawyer solicitation would seem already to be covered by the FTC Cooling-Off Rule. The Rule applies to a

sale, lease, or rental of consumer goods or services with a purchase price of $\$ 25$ or more . . . in which the seller or his representative personally solicits the sale, .... and the buyer's agreement or offer to purchase is made at a place other than the place of business of the seller.

16 C.F.R. $\S 429.1$ note 1 (a) (1985). "Consumer goods or services," id. at note 1(b), appear to include personal legal services purchased by individuals, such as tax advice, divorces, wills, and so forth. Legal services are not among the listed exemptions to the rule. See $i d$. at note $1(\mathrm{a})(4)$ (exempting transactions conducted entirely by mail or telephone); $i d$. at note 1 (a)(6) (exempting real estate, insurance, and security sales). Nevertheless, soliciting for legal services clearly was not the type of solicitation the FTC sought to regulate by the Rule. The Rule has apparently never been applied to legal solicitation.

${ }^{268}$ See FTC: Cooling-Off Period, supra note 100, at 22,934 (1972); McChesney, supra note 258.

${ }^{267}$ Ohralik, 436 U.S. at 464. 
cooling-off period could be handled by allowing clients to rescind their contracts at any time without cause and pay only in quantum meruit.

There are other alternatives for correcting deception that the Court did not consider. Although fraud and deception can (and doubtless do) occur in every industry, almost all of the problems are handled case-by-case as they arise. For example, every state legislatively outlaws "unfair and deceptive acts and practices." 268 There is no evidence that treating problems of deception in professional promotion cannot be handled adequately under such statutes; indeed, the more liberal jurisdictions already judge lawyer advertising solely under these general criteria. ${ }^{269}$ In England, advertising by solicitors was traditionally allowed, subject only to scrutiny to avoid misleading the public. ${ }^{270}$ This standard is the one established in the new ABA Model Rules, not just for advertising, but for use of trade names. ${ }^{271}$ Virginia and Washington, D.C. have similar rules on solicitation, allowing it in all but carefully limited circumstances, and have apparently experienced no unusual deception problems. ${ }^{272}$ In general, the beneficial results of liberalized promotional

268 See supra note 56.

${ }^{269}$ In Wisconsin, for example, the state bar reacted to the Bates decision by proposing a "very narrow and specific set of rules which prohibited any form of advertising not addressed by the Bates court." Note, 67 MARQ. L. REv. 168, 171 (1983) (footnote omitted). The Wisconsin Supreme Court rejected the proposals and prohibited only advertising that is false, deceptive, or misleading. Thus the Wisconsin rules "treat advertising by lawyers no differently from advertising generally." Id. at 172 (footnote omitted). Similarly, the Court of Appeals of Maryland, on its own motion, replaced the restrictive rules submitted by the state bar with rules that would prohibit only false or misleading advertisements, advertisements likely to create unjustified expectations of favorable results, or advertisements facilitating otherwise unlawful acts. $5 \mathrm{Md}$. Admin. Reg. 56 (1978); see Comment, Attorney Advertising in Maryland: A Need for Stricter Control, 13 U. Balt. L. REv. 92, 105-08 (1983).

270 See Attanasio, supra note 9, at 495-96. The evolution of the English rules surrounding solicitor advertising offers considerable support for the predatory view of promotional restrictions explained in this article. See supra text accompanying notes 196-211. Solicitor advertising was permitted as long as the courts themselves regulated solicitors. In 1933, however, Parliament shifted regulatory responsibility to the English Law Society, the professional association of solicitors. The following year, the Law Society adopted prior restraints on "touting," which it defined as attracting business by undercutting statutory or customary rates. In 1936, the Law Society included solicitor advertising as "touting," and so banned it. See Attanasio, supra note 9, at 495-96.

${ }^{271}$ See Model Rules of Professional Conduct Rules 7.2, 7.5(a) (1983).

272 See Disciplinary Rules of the District of Columbia Bar, DR 2-103(A) (1981). The District of Columbia rule essentially prohibits only solicitation that is false, solicitation that constitutes undue influence, or solicitation that targets a person unable to exercise reasonable judgment in selecting a lawyer. The District's favorable experience with liberal solicitation rules is noted in Attorney Solicitation: The Scope of State Regulation After Primus and Ohralik, 12 U. Mrch. J. L. REF. 144, 180 (1978); see also McGrath Letter, supra note 15, at 6 ("After checking with Bar Counsel in the District of Columbia and Virginia, we are aware of no evidence that their adoption of such [liberal] rules has led to solicitation fraught with 'undue influence, intimidation and over-reaching' of the public."). 
rules have stood in "stark contrast to the ogre predicted by the doomsayers."27s

Up to this point, one alleged remedy for deception, bar requirements for inclusion of additional information in commercial speech, has not been considered here. The omission is intentional. The additional information required to supplement potentially deceptive speech may be just as misleading to an audience as the original message itself, however truthful but incomplete the first message was. ${ }^{274}$ Worse, as long as the bar need not specify ex ante precisely the sorts of information that must be disclosed in an ad, ${ }^{275}$ it can always allege, after the fact, that information necessary to avoid deception was omitted. The lawyer is placed in a no-win situation. No advertisement or other commercial message

Joe Sims has observed that

there is as yet no sign that the moral or professional (assuming there is a difference) fabric of the D.C. Bar has unraveled as a result of [its] standard, nor is there any evidence that that rule has had any adverse effects on the consumers of legal services. ...

-...

... Since the Virginia Bar has not yet crumbled [after adopting solicitation rules similar to those in D.C.], perhaps less traditional states will now be encouraged to join the parade.

Sims, supra note 112 , at 14 , col. 4,19 , col. 3 .

273 Attanasio, supra note 9, at 540 .

274 A review of the empirical evidence on corrective advertisements and affirmative disclosures in advertising concludes that "remedial statements may be at least as confusing and misleading as the advertising they are designed to counteract." Jacoby, Nelson \& Hoyer, supra note 225, at 62 (citing prior studies of audience comprehension of corrective advertising). Lawyers are generally not experts at appraising the inferences consumers will make from mandated additional disclosures. "The difficulty involved in accurately communicating meaning is often underestimated, and regulators would seem to be no exception in this regard." Id. at 68.

For a good example of judicial sensitivity to this problem, see Spencer v. Honorable Justices of the Supreme Court, 579 F. Supp. 880 (E.D. Pa. 1984). In that case, the court invalidated a state requirement that a lawyer promoting himself as limiting his practice to certain areas also include a disclaimer that he was not recognized or certified as a specialist in those fields. The court reasoned:

By requiring a lawyer to state clearly that he or his law firm is neither recognized nor certified as a specialist in any limited field of practice, [the rule] contains the possible implication that the advertising lawyer is not a recognized or certified specialist but that other lawyers may be. . . . Such a negative implication may cause lawyers to decline to list any fields of concentration simply to avoid the requirement of including the damaging disclaimer. This would be unfortunate because useful and otherwise protected information concerning the nature of a lawyer's practice would be suppressed.

Id. at 891-92 (footnote omitted).

${ }_{278}$ See Zauderer v. Office of Disciplinary Counsel, 105 S. Ct. 2265, 2282 (1985)

(A state is free to specify, after the fact, what additional information should have been included "as long as disclosure requirements are reasonably related to the State's interest in preventing deception of consumers."). 
can possibly contain all the information of relevance to a consumer purchase decision. Rather, an ad may suggest that a consumer consult a professional for further information. In a subsequent consultation, more complete and precise information can be made available. Demanding that all relevant information be included in a commercial message ignores the interplay between the initial message and the follow-up meeting in informing consumers.

The possibility that a lawyer will be disciplined for failure to include additional information in a truthful commercial message will reduce the number of messages that attorneys will disseminate in the first place. The likelihood that ex post disclosure requirements will be used to discipline lawyers is even greater if the bar uses mandatory disclosure predatorily. Suspicions as to the bar's motives are not allayed by observation of the bar's reaction when lawyers seek guidance as to whether additional information should be included in commercial messages. In Zauderer v. Office of Disciplinary Counsel, ${ }^{276}$ for example, the attorney had submitted his advertisement to the bar for its review and advice. The bar refused to advise him, waited until the advertisement had run and then initiated disciplinary proceedings for failure to disclose necessary additional information. 277

In summary, although restrictive regulatory solutions for deception may be appropriate, the Court itself recognized in the advertising cases that the state bars may have a tendency to exaggerate the extent of any problem. As the experience with alleged deception in door-to-door selling indicates, before approving the most drastic remedy available-complete prohibition of the particular form of speech involved-the Court should require better empirical evidence on the magnitude of deception. In addition, the Court should reexamine less drastic means of mitigating genuine problems of deception.

\section{CONCLUSTON}

Withholding constitutional protection from commercial speech

278105 S. Ct. 2265 (1985).

${ }^{277}$ See id. at 2289 (Brennan, J., concurring in part and dissenting in part); see also Leoni v. State Bar of California, 704 P.2d 183, 186-87, 217 Cal. Rptr. 423, 427 (1985) (After receiving an outline of attorneys' direct mail campaign and copies of letters to be mailed, the California Bar thanked them for their "good intentions" and then waited for two years while the campaign continued before beginning disciplinary proceedings.). In Leoni, the California Supreme Court reduced the 30-day suspension imposed on the attorneys to a public reprimand and commented that "[w]e hope the State Bar will assist its members in acting in accordance [with the solicitation rule], rather than, as in the instant case, only initiating disciplinary proceedings." Leoni, 704 P.2d at 195, 217 Cal. Rptr. at 435. 
when there is merely a possibility that it will mislead, as the Supreme Court has done with nonadvertising forms of commercial speech, is inconsistent with the policy and the analysis of the commercial speech doctrine as it originally developed. In Bates $v$. State Bar of Arizona, ${ }^{278}$ the majority rejected dissenting Justice Powell's argument that advertising would necessarily mislead some consumers and so could constitutionally be banned. Yet the Court accepts the same deception rationale in upholding bans on other commercial speech-speech which is no more inherently deceptive than advertising. All forms of commercial speech can be deceptive; all can be truthful. The Court has not articulated any constitutional justification for applying different burdens of proving deception when different forms of commercial speech are challenged. Furthermore, the Court has not explained why states are not limited to least restrictive alternatives in regulating nonadvertising deception, as they are when deception comes via advertising.

Aside from contradictions and inconsistencies in the Court's commercial speech opinions, the Court has failed to consider a point raised by lawyers, judges, and other commentators: the possibility that promotional restrictions have much less to do with protecting consumers than with hobbling those professionals to whom promotion is particularly useful. "To many lawyers, the main 'evil of unrestricted solicitation' is its pro-competitive potential." 279 The Court noted in Bates that "cynicism with regard to the [legal] profession may be created by the fact that it long has publicly eschewed advertising, while condoning the actions of the attorney who structures his social or civic associations so as to provide contacts with potential clients." 280 The cynicism created by the Court's treatment of solicitation and trade names may be no less. Particularly unfortunate is the ease with which the professional associations have convinced the Court of the purity of their motives in ferreting out deception.

This article suggests that stated concerns about deception may mask predatory reasons for traditional restrictions on promotion. If it is

278433 U.S. 350 (1977).

${ }^{279}$ Sims, supra note 12 , at 59 .

280 Bates, 433 U.S. at $370-71$. One example of such cynicism on the part a prominent non-lawyer is the following:

One of the greatest failings of the organized bar in the past century . . . is that it has fought innovations. When greater competition has come to the legal profession, .... when lawyers have begun to advertise or compete-in short, when the profession has accommodated the interests of the public- - [the bar] has done so only when forced to.

President Carter's Attack on Lawyers, President Spann's Response, and Chief Justice Burger's Remarks, 64 A.B.A. J. 840, 845 (1978) (President Carter's speech). 
in some professionals' interest to advertise or solicit, it may be in their competitors' interest to prevent advertising and solicitation. Given that small-firm and less-established lawyers find advertising, solicitation and referral fees more useful than others do, there can be no question that the bar's traditional restrictions on promotion have hurt these two groups of attorneys. There is no direct evidence that the bar has been anything but an unwitting participant in reducing competition. But the bar's preference for combatting deception by the draconian measure of banning even beneficial commercial speech is perhaps telling. The alacrity with which the organized bar and other professional associations throw the baby out with the bath-water strongly suggests that they want to get rid of both. 


$$
\text { . }
$$

